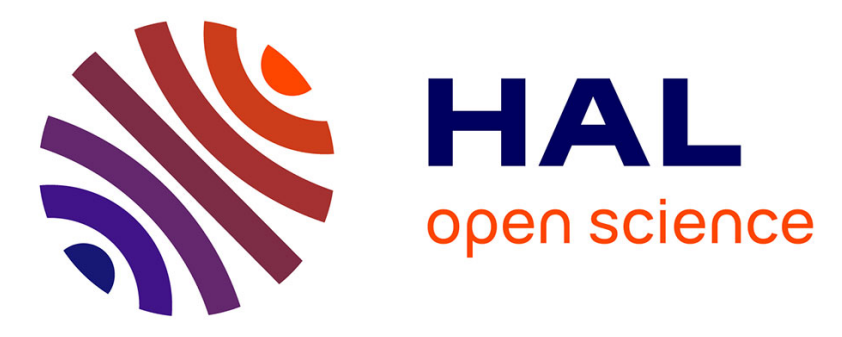

\title{
Drivers of the distribution of spontaneous plant communities and species within urban tree bases
}

Mona Omar, Nazir Al Sayed, Kévin Barré, Jalal Halwani, Nathalie Machon

\section{To cite this version:}

Mona Omar, Nazir Al Sayed, Kévin Barré, Jalal Halwani, Nathalie Machon. Drivers of the distribution of spontaneous plant communities and species within urban tree bases. Urban Forestry and Urban Greening, 2018, 35 (October 2018), pp.174-191. 10.1016/j.ufug.2018.08.018 . hal-01955338

\section{HAL Id: hal-01955338 \\ https: / hal.sorbonne-universite.fr/hal-01955338}

Submitted on 14 Dec 2018

HAL is a multi-disciplinary open access archive for the deposit and dissemination of scientific research documents, whether they are published or not. The documents may come from teaching and research institutions in France or abroad, or from public or private research centers.
L'archive ouverte pluridisciplinaire $\mathbf{H A L}$, est destinée au dépôt et à la diffusion de documents scientifiques de niveau recherche, publiés ou non, émanant des établissements d'enseignement et de recherche français ou étrangers, des laboratoires publics ou privés. 


\title{
Drivers of the distribution of spontaneous plant communities and species within urban tree bases
}

\author{
Mona Omar $^{\mathrm{a}, \mathrm{c}, *}$, Nazir Al Sayed ${ }^{\mathrm{b}}$, Kévin Barré ${ }^{\mathrm{a}}$, Jalal Halwani ${ }^{\mathrm{c}}$, Nathalie Machon ${ }^{\mathrm{a}}$ \\ ${ }^{a}$ Centre d'Ecologie et des Sciences de la Conservation (CESCO, UMR7204), Sorbonne Université, MNHN, CNRS, UPMC, CP135, 61 rue Buffon, 75005 Paris, France \\ ${ }^{\mathrm{b}}$ Faculty of Engineering, Lebanese University, Tripoli, Lebanon \\ ${ }^{c}$ Water \& Environment Science Laboratory, Faculty of Public Health, Lebanese University, Tripoli, Lebanon
}

Keywords:

Bercy

Paris

Plant communities

Spontaneous flora

Urban biodiversity

Urban tree bases

Urbanized zones

\begin{abstract}
A B S T R A C T
Many studies have shown that the quality of biodiversity influences the well-being of citizens. Nevertheless, the drivers that shape biodiversity in urbanized zones are poorly understood. Although tree bases present reduced surface areas, they occur in great numbers in a deliberate spatial arrangement and may play an important ecological role in urban environments by offering limited favorable spaces for the development of spontaneous flora. The purpose of this study was to identify the factors that influence the composition of plant communities harbored by tree bases in an urban district. We analyzed floristic inventory data collected in 2014 about plants growing at the bases of the 1474 trees on the 26 streets of the Bercy district in Paris (France).

Our results indicated that the plant communities growing in the urban tree bases varied according to different factors. The abundance and distribution of these species were dependent on their biological traits (seed longevity in the soil bank) as well as the tree base characteristics (tree trunk diameter, equipment type around the tree bases, soil compaction, animal excrement, solar radiation, and urban tree species), the street orientation according to the air flow following the Seine River, and the geographic structure of the district (the influence of the presence of green spaces). The results of this study showed that the tree bases could be considered favorable stepping-stone habitats for certain species between more important green spaces such as parks and gardens. Thus, these areas actively participate in the enhancement of urban biodiversity.
\end{abstract}

\section{Introduction}

Understanding the mechanisms that generate the spatial distributions of organisms at different spatial scales is one of the major goals of ecology (Wiens et al., 1993). Cities may be especially valuable for elucidating these mechanisms for plant communities through the study of the environmental filters described by Lortie et al. (2004). These filters are supposed to select species according to their traits, in relationships with the environmental characteristics (warmer climates due to the urban heat island (UHI), pollution, and drought), the human practices they are subjected to (Williams et al., 2015) and the fragmentation of habitats.

Thus, plant functional traits could be used to identify some community assembly processes (Kraft et al., 2015). For example, traits linked to dispersal vectors are commonly investigated in urban plant trait studies because fragmentation induced by urbanization may have an impact on gene flow among populations (McGarigal and Cushman, 2002). In fact, according to Howe and Smallwood, 1982; Willson and Traveset, 2000; Zipperer et al., 2000; and Bierwagen, 2007, fragmentation seems to impede gene flow among populations, which may be critical for the movement of populations, despite Fahrig's review (2017) showing that, through many possible processes (i.e., increased functional connectivity, habitat diversity, positive edge effects, reduced competition, the spreading of risk, and landscape complementation), fragmentation could also lead to positive ecological responses.

The longevity of seeds in the soil is also a trait that is worth studying because plants with extensive seed banks are known to contribute to the buildup of remnant population systems in which many local populations persist over long periods and withstand unfavorable conditions (Eriksson, 1996). Plant species with long-lived seeds are expected to be favored in cities, where disturbances are frequent and rather unpredictable (Westermann et al., 2011).

* Corresponding author at: UMR 7204 - CESCO - CP135, Muséum national d'Histoire naturelle, Département Homme et environnement, 61 rue Buffon, 75005 Paris, France.

E-mail addresses: mona.omar@edu.mnhn.fr (M. Omar), nazir.alsayed@gmail.com (N. Al Sayed), kevin.barre@mnhn.fr (K. Barré), jhalwani@ul.edu.lb (J. Halwani),nathalie.machon@mnhn.fr (N. Machon). 
Spontaneous native urban vegetation has commonly been described as demonstrating resilience (Ignatieva et al., 2000) and exhibiting adaptations to human disturbance (Lundholm and Marlin, 2006; Sukopp, 2004). According to Walter (1971), cities generally host a higher number of vascular plant species than rural areas of the same size. Most animal and plant species in cities dwell in diverse habitats including parks, public gardens (Shwartz et al., 2013), flowerbeds, lawns, river banks, railways and green spaces at business sites (Serret et al., 2014). Among these habitats, the bases of urban-aligned trees represent particular micro-green spaces, and their numbers in certain cities (more than 100,000 in Paris (Contassot, 2008)) indicate a significant influence on the quality of the biodiversity in these cities (Pellegrini and Baudry, 2014; Schmidt et al., 2014). These trees can also harbor a number of plant species, especially in streets where there is limited management and trampling.

Few studies have examined the species that grow in these small public spaces. Due to good knowledge of the urban territory and intensive inventories of the flora in tree bases, it may be possible to determine the distribution of species according to their traits, to environmental features and to the district structure with respect to its layout and the location of green spaces among the streets. It may also be likely to determine the respective role of these factors at the local level (patch effects), street level and district level (urban matrix effects) on the distribution of species.

Thus, the aim of this paper was to describe the plant communities growing at the base of urban trees in a district of Paris (Bercy, the $12^{\text {th }}$ arrondissement) (Fig. 1) and to elucidate the drivers of community compositions. This district was chosen for its high number in alignment trees. Furthermore, it is situated in the neighborhood of the Seine River and the urban Vincennes Wood and includes a large park (Bercy Park) and the Lyon and Bercy railway stations, which could represent sources for certain plant populations in the streets. For this purpose, we listed the plant species that were growing in the 1474 tree bases of the district in 2014 and attempted to explain their abundance and distribution according to their biological traits as well as the tree base, street and district characteristics. The results are intended to assist in improving management practices relating to urban biodiversity.

\section{Methods}

\subsection{Study area}

The study area is located in the 12th arrondissement (i.e., administrative district) of Paris, the capital city of France (the World Geodetic System 1984 reference is $48^{\circ} 50^{\prime} 26.91^{\prime \prime} \mathrm{N}, 2^{\circ} 23^{\prime} 17.46^{\prime \prime} \mathrm{E}$ ); the area covers an area of approximately $6.38 \mathrm{~km}^{2}$ and contains 26 streets that are primarily lined by buildings (some with small gardens), railways (Bercy and Lyon stations) and a large public garden (Bercy Park). The study area lies on the north side of the Seine River and the west side of Vincennes Wood, and its human population is approximately 144,000 inhabitants, which is equivalent to approximately 23,000 inhabitants/ $\mathrm{km}^{2}$ (INSEE, 2017)

Our study included all 26 streets and avenues in the district that were planted with alignment trees. In these streets, all 1474 bases (hereafter called "patches") of trees planted linearly and regularly on the pavements were inventoried. The patch areas around the tree bases were more or less constant all over the district (1-2 $\mathrm{m}^{2}$, Fig. 2). These streets are all managed similarly and during the same period; they are subjected to the regular elimination of vegetation (most of the roots included) once a year in October by using weeders as hoes in addition to brush-cutters. For tree bases equipped by grills, this equipment is removed during the weeding task by the city workers, according to the testimony of the technical services in charge of cleaning the streets.

\subsection{Floristic inventories}

The 1474 patches were inventoried (Fig. 1, Appendix A) once for all of the wild vascular plant taxa in May or June of 2014.

The survey was based on the presence/absence of each species per tree. Only ten tree bases of the 1474 total hosted intentionally cultivated horticultural plants. We deliberately chose to exclude the "cultivated vegetation" from the study, because these species are chosen according to human preferences and their study fits into another research field (see Knapp et al., 2008; Kendal et al., 2012) and because of their very low abundance in the district. Thus, we restricted our study to natural and spontaneous flora.

The determination of the species was performed with the French flora (Tison and de Foucault, 2014). The taxonomic reference for the species was the French Flora Reference TAXREF v8.0 (Gargominy et al., 2014).

All of the statistical analyses were performed with $\mathrm{R}$ version 3.0.2 (Team, 2013). The statistical analyses were performed according to the presence or absence of all the species, but they were deepened for those hosted by more than 50 tree bases (hereafter called "the abundant species”).

\subsection{Community level}

\subsubsection{Characteristics of the district, street and tree base level}

The species richness (S) and the number of insect-pollinated species (NIPS) were quantified on the basis of the inventories. Because pollination success may be negatively affected by the impervious surfaces in the neighborhood (Pellissier et al., 2012), we suspected that tree bases that were too distant from green spaces could be devoid of insects. The NIPS was examined to identify the patches that may have been frequented by insects and thus probably hosted multitaxon interactions. The determination of the NIPS was performed with BIOLFLOR (Trait Database of the German Flora: http://www.ufz.de/biolflor, Kühn et al., 2004). For each species, we also recorded its dispersal mechanism (anemochorous, epizoochorous and barochorous species) according to the Tela Botanica website (http://www.tela-botanica.org).

At the district level, we examined the influence of the presence of large green spaces (parks, woods, etc.) on the species richness and NIPS. Geographic Information System ArcGIS 10.2 software (ESRI 2013) was used to calculate the smallest Euclidean distance of each of the tree bases from the borders of the railway stations, Bercy Park, the Seine River and Vincennes Wood. We verified that the influence of other ruderal sites, all much smaller than the studied ones, had a negligible influence on the tree base vegetation because they were masked by the effect of larger ones when we were previously testing the effects of Square Saint-Eloi and the garden of Reuilly (two secondary green spaces by size) on the species richness and NIPS, which were not significant (results not shown).

At the street level, we studied the possible effects of the street orientation according to the air flow following the Seine River to see if it was parallel (i.e., subjected to the air flow) or perpendicular (i.e., protected by buildings bordering the streets). The street orientation was deduced from district satellite images (Appendix A). Previous tests (Fisher tests, not shown) indicated that parallel and perpendicular streets do not show any significant difference in pedestrian frequency or the quantity of traffic.

At the tree base level, we tested the possible effects of the following: (1) the equipment types around the tree bases (no equipment, partially covered, or totally covered); (2) the soil compaction (whether the soil was compacted by pedestrians or not), as estimated by the observers after verifying the capacity of the human eye to discriminate this characteristics with a pocket penetrometer on ten tree bases (non compacted, i.e., penetration resistance values lower than $2 \mathrm{~kg} / \mathrm{cm}^{2}$; compacted soil has a penetration resistance value (prv) greater than $2 \mathrm{~kg} / \mathrm{cm}^{2}$ (Vaquero, 2005)); (3) the presence of animal excrement; and 


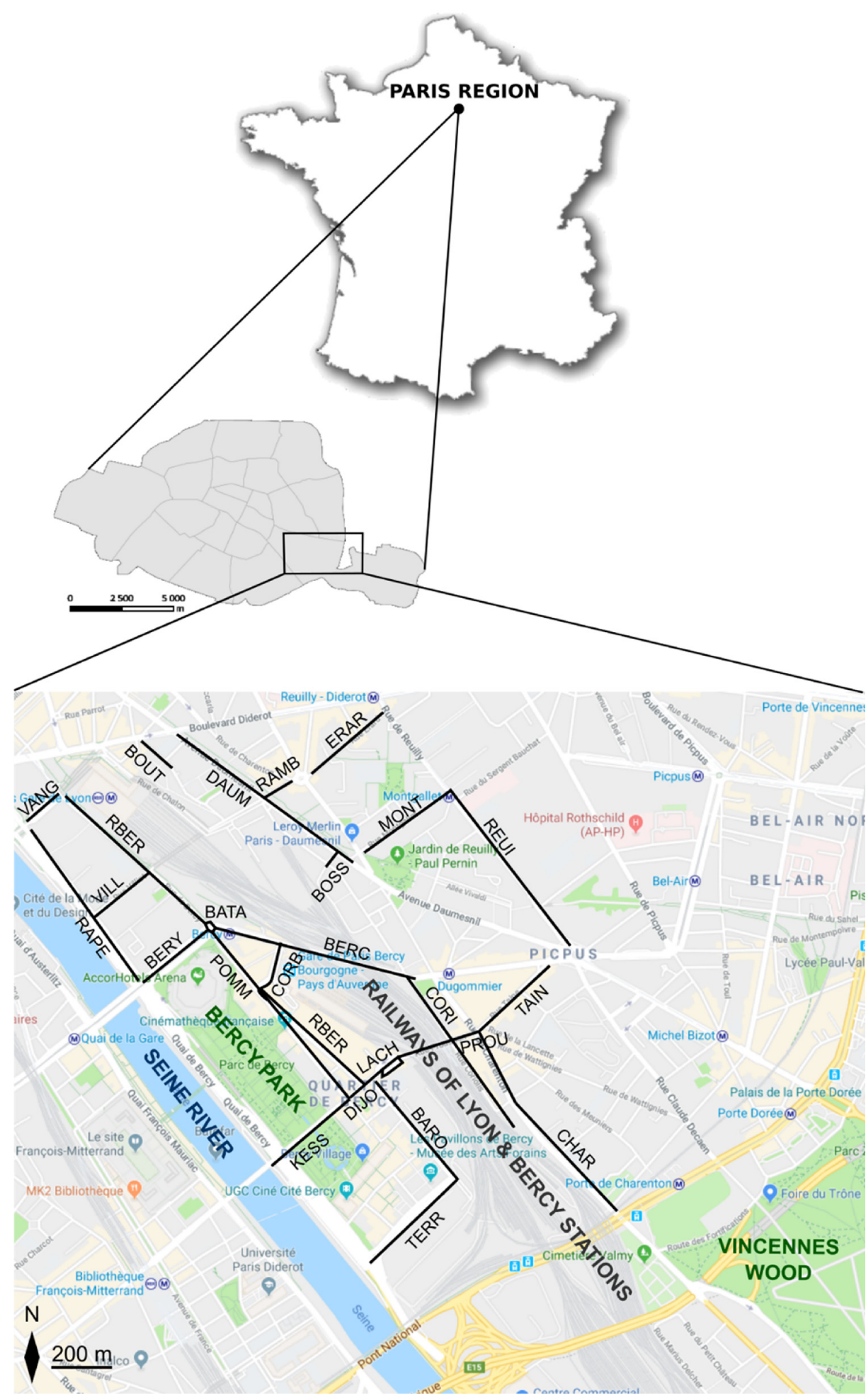

Fig. 1. Map of the Bercy district in the $12^{\text {th }}$ arrondissement of Paris (France) where the floristic inventories were taken. From Maurel, (2010). The names of the streets are given in Appendix A.

(4) the planted tree species (Platanus x hispanica Miller ex Münchh., Ailanthus altissima (Mill.) Swingle, Prunus armeniaca L., Tilia cordata Mill, Aesculus hippocastanum L., Carpinus betulus L., and Robinia pseudoacacia L.), the information of which was deduced from field observations; and (5) the tree trunk diameter at breast height (DBH), which was measured at 4.5 feet $(1.4 \mathrm{~m})$ above the ground with a calibrated diameter tape wrapped around the circumference of the trees (Lawson, 1967; Lewis, 1989).

To examine the potential impact of light on the communities, we also calculated the effect of the solar light received by each tree base using the solar map provided by Apur (Paris Urbanism Agency) that indicated the level of exposure in $\mathrm{kWh} / \mathrm{m}^{2} / \mathrm{yr}$ per $250 \mathrm{~cm}^{2}$ pixel as 
A

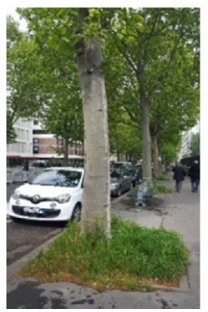

B

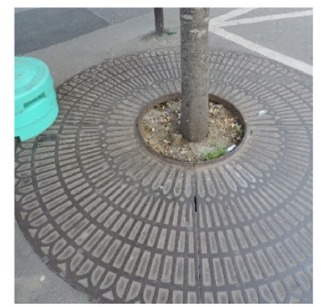

$\mathrm{C}$

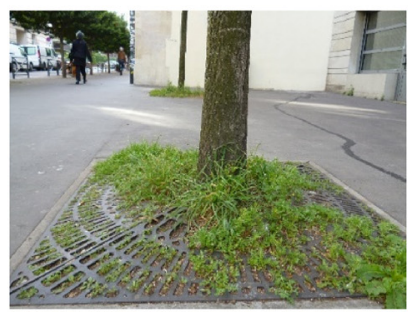

$\mathrm{D}$

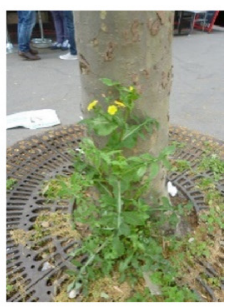

Fig. 2. Pictures illustrating the tree base coverings: (A) tree base without equipment, (B) tree base totally covered, (C) \& (D) tree bases with partial grills. Examples of a frequent type of spontaneous vegetation in tree bases in Paris (Poa annua (A) \& (C), Sonchus oleraceus (D), and Stellaria media (C)).

calculated from the simulation of the average annual solar radiation, and by considering the effects of shadows from buildings (Besse, 2011). We then calculated the mean insolation value of each tree base using ArcGIS 10.2 software. These values varied from $17,000 \mathrm{~kW} / \mathrm{m}^{2} / \mathrm{yr}$ to $1,115,000 \mathrm{~kW} / \mathrm{m}^{2} / \mathrm{yr}$, which we transformed by natural logarithm. Partial grills affect access to light under the grills, but we assumed that, in the holes, the light is the same as it is in tree bases without grills (which is true when the vegetation is a few centimeters high).

\subsubsection{Statistical analysis at the community level}

To determine which factors have an influence on the species richness and NIPS per tree base, we used a generalized linear model. First, we used the cor function with the Spearman method to reveal possible correlations among the tested factors (Kendall, 1938). None of the variables were correlated (results not shown). We then used the variance inflation factors (VIFs) from the R package "car" (Fox et al., 2017) to discard the possible variables that generated excessive collinearity with the other variables in full models. All the variables showed VIF values $<5$, meaning there was no striking evidence of multicollinearity (Chatterjee and Hadi, 2015). The spatial autocorrelation was also tested among the residuals of the models using the Mantel test, and we obtained nonsignificant spatial autocorrelation in all cases. We thus assumed that spatial autocorrelation was either absent or negligible. We fitted a generalized additive model (GAM) to the data with the $\mathrm{R}$ package "mgcv" (Wood, 2017) to explore the potential need for the quadratic transformation of variables in generalized linear models (GLMs). We then used the glm.nb function in the R Package "MASS" (Venables and Ripley, 2002) to study the possible effect of the six following factors and their one-on-one interactions: (1) the influence of the smallest Euclidean distance from each of the green spaces on the species richness and NIPS; (2) the tree species; (3) the tree base equipment; (4) the soil compaction; (5) the tree trunk diameter; (6) the natural logarithm of the solar radiation; and (7) the presence of animal excrement within each tree base.

We performed an ANOVA to test whether the difference in the mean species richness and NIPS was statistically significant. We also examined the relative variance-explained calculation using adjusted Rsquared results for the models. We used the Bonferroni-Holm method to adjust the p-values when performing these multiple statistical tests (Armstrong, 2014).

Tukey's "honestly significant difference" method was applied using the glht function in the $\mathrm{R}$ "multicomp" package (Ruxton and Beauchamp, 2008) to identify which groups were significantly different from the others.

For species richness and NIPS, there was no striking evidence of overdispersion in the models since the values ranged from 0.8 to 1.25. We validated the models by checking the residual plots. The observed residuals were consistent with the stochastic errors.

\subsection{Species distribution}

We deepened the study for the 28 species that were present with an occurrence of at least 50 patches of the 1474 , hereafter called "the abundant species". The other species could not be subjected to the following analyses due to a lack of sufficient data.

\subsubsection{Characteristics of the district, street and patch levels}

We examined the species distribution among the 1474 patches, i.e., for each species, we recorded the patches in which they were present and absent. The species abundance was estimated as the number of patches that were occupied in the study district (Table 1).

At the district level, we intended to examine the influence of green spaces, which represent a potential source of seeds, on the presence of each of the abundant species.

At the patch level, we studied the effects of (1) the tree base

\section{Table 1}

The names of the 28 abundant species, their I $\delta$ value, and the species abundance as well as the $\mathrm{R}^{2} \mathrm{c}$ and the $\mathrm{R}^{2} \mathrm{~m}$ for each species. For mixed-effects models, the marginal $\mathrm{R}^{2}$ is the part of variance explained by the following fixed factors: (1) the tree base equipment, (2) the soil compaction, (3) the tree species, (4) the natural logarithm of the solar radiation, (5) the presence of animal excrement and (6) the influence of the smallest Euclidean distance from each of green spaces on the presence/absence of the abundant species; conditional $\mathrm{R}^{2}$ is explained by both fixed and random factors (streets).

\begin{tabular}{lllll}
\hline Species & $\mathrm{I} \delta$ & Species abundance & $\mathrm{R}^{2} \mathrm{~m}$ & $\mathrm{R}^{2} \mathrm{c}$ \\
\hline Cerastium glomeratum & 4.35 & 50 & 0.09 & 0.12 \\
Plantago lanceolata & 3.07 & 68 & 0.28 & 0.29 \\
Cirsium arvense & 2.36 & 54 & 0.25 & 0.27 \\
Lolium perenne & 2.17 & 93 & 0.07 & 0.09 \\
Picris echioides & 1.85 & 64 & 0.11 & 0.13 \\
Parietaria judaica & 1.73 & 58 & 0.12 & 0.15 \\
Torilis japonica & 1.72 & 66 & 0.07 & 0.16 \\
Epilobium tetragonum & 1.59 & 65 & 0.08 & 0.23 \\
Veronica persica & 1.57 & 68 & 0.11 & 0.18 \\
Veronica arvensis & 1.55 & 90 & 0.09 & 0.10 \\
Chenopodium album & 1.34 & 105 & 0.23 & 0.25 \\
Senecio vulgaris & 1.31 & 115 & 0.11 & 0.23 \\
Lactuca serriola & 1.26 & 155 & 0.31 & 0.35 \\
Matricaria recutita & 1.25 & 205 & 0.34 & 0.37 \\
Geranium molle & 1.21 & 58 & 0.15 & 0.17 \\
Senecio inaequidens & 1.17 & 77 & 0.12 & 0.15 \\
Capsella bursa-pastoris & 1.15 & 294 & 0.14 & 0.18 \\
Polygonum aviculare & 1.14 & 181 & 0.38 & 0.42 \\
Hordeum murinum & 1.08 & 584 & 0.27 & 0.30 \\
Sonchus asper & 1.05 & 60 & 0.07 & 0.13 \\
Plantago major & 1.03 & 107 & 0.11 & 0.17 \\
Picris hieracioides & 1.01 & 64 & 0.20 & 0.23 \\
Sisymbrium irio & 0.98 & 261 & 0.24 & 0.27 \\
Stellaria media & 0.93 & 224 & 0.14 & 0.16 \\
Sonchus oleraceus & 0.83 & 390 & 0.19 & 0.22 \\
Taraxacum campylodes & 0.82 & 662 & 0.25 & 0.29 \\
Conyza canadensis & 0.81 & 666 & 0.04 & 0.07 \\
Poa annua & 0.75 & 1175 & & \\
\hline & & & & \\
\hline
\end{tabular}


A

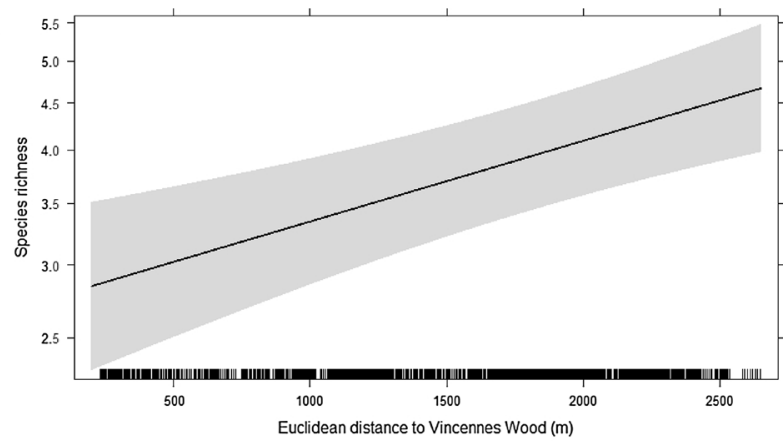

B

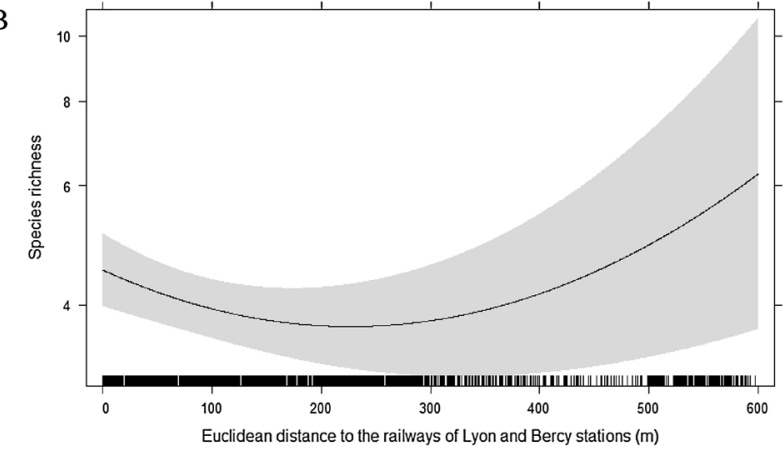

C

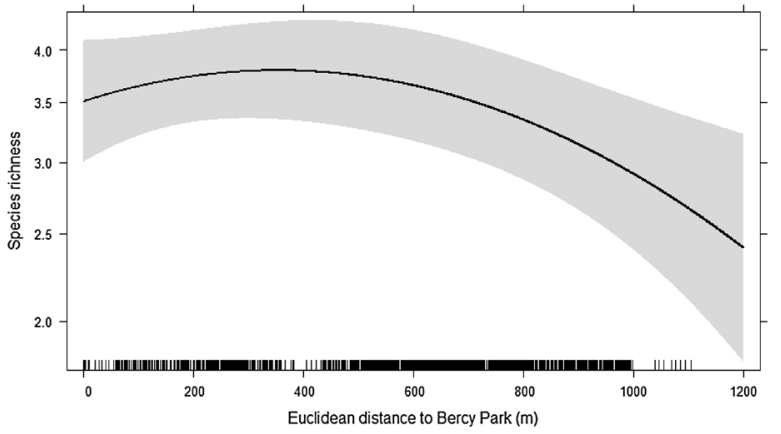

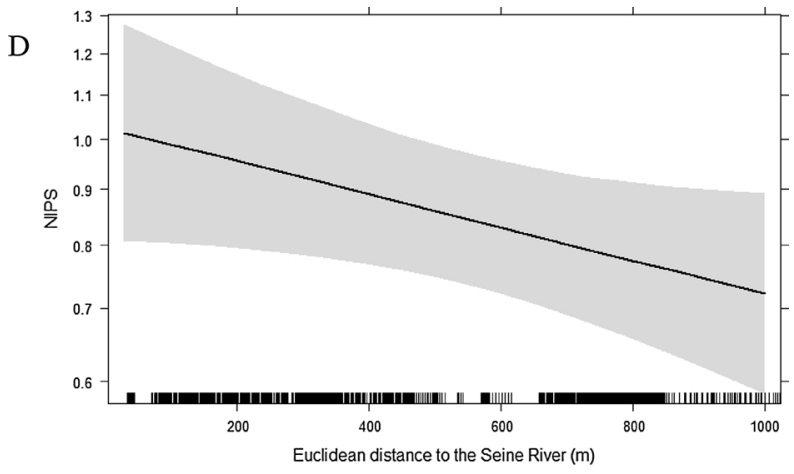
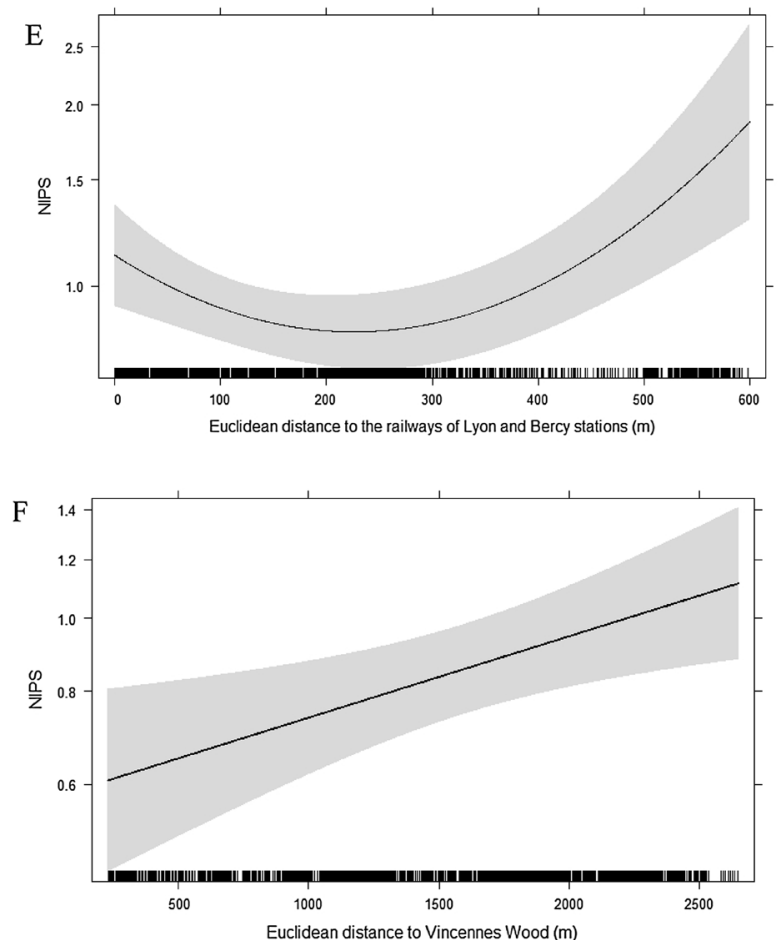

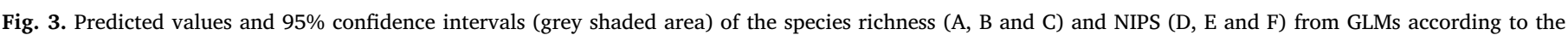

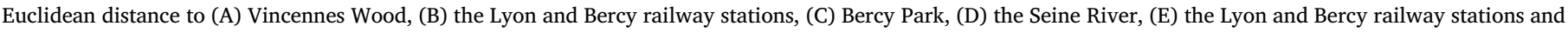
(F) Vincennes Wood. The vertical dense lines at the bottoms of the figures show each tree base observation.

equipment, (2) the soil compaction, (3) the tree species, (4) the natural logarithm of the solar radiation and (5) the presence of animal excrement on the presence/absence of the abundant species.

\subsubsection{Statistical analysis on species distribution}

For each of the abundant species (i.e., $>50$, Table 1), we used the "glmer" function in R package lme4 ((Bates et al., 2014), R software 3.0.2) for fitting a generalized linear mixed-effect model (GLMM) using the binomial distribution to test, in their presence, the effect of the variables above, exerting a random effect on the street variable. We used the cor then the vif.mer functions to discard the possible variables that generated excessive collinearity with the other variables in the full models; there was no striking evidence of multicollinearity. The spatial autocorrelation was also tested among the residuals of the models using the Mantel test, and we obtained nonsignificant spatial autocorrelation in all cases. We thus assumed that the spatial autocorrelation was either absent or negligible. An ANOVA ( $\mathrm{R}$ package car) using the street as a random factor was performed to test whether the differences in the means were significant. We used the Bonferroni-Holm method to adjust the probability when making these multiple statistical tests for each of the 28 abundant species.

For the mixed-effects models, we then calculated the marginal $R^{2}$ (the part of the variance explained by the fixed factors), and the conditional $\mathrm{R}^{2}$ (as explained by both fixed and random factors) (Nakagawa and Schielzeth, 2013) using the r.squaredGLMM function from the MuMIn package (Barton, 2009).

Moreover, there was no striking evidence of overdispersion in the models since the values ranged from 0.8 to 1.25 . We validated the models by checking the residual plots. The observed residuals were consistent with the stochastic errors.

\subsubsection{Biological characteristics of the abundant species}

For the abundant species, 100 dry seeds issued from the Seed Bank of the National Museum of Natural History (BGM) were weighed and examined to determine if they originated from dispersal parts (wing, pappus, etc.). The longevity of the seeds in the soil seed banks was deduced from (Thompson et al., 1997), and the species were classified into the following categories: (1) transient, (2) short-term or (3) longterm persistent according to whether the seeds were known to persist in the soil for (1) less than one year, (2) at least one year or (3) at least five years, respectively.

Furthermore, because the species may be more or less randomly distributed over the district, we wanted to characterize their distribution as "aggregated" or "spread." Following Morisita (1959a, 1959b), 
we divided the district into $g$ groups of ten consecutive tree bases. For each species, we counted the number $n_{i}(i=1,2,3, \ldots g)$ of tree bases occupied by the species in each group. $\mathrm{N}$ is the total number of tree bases occupied by the species as follows:

$N=\sum_{i=1}^{g} n i$

where $\delta$ corresponds to the unbiased estimate of Simpson's measure of diversity (Simpson, 1949):

$\delta=\frac{\sum_{i=1}^{g} n i(n i-1)}{N(N-1)}$

Then, for each of the abundant species, we calculated $\mathrm{I}_{\delta}=\mathrm{g} \delta$.

$\mathrm{I}_{\delta}$ is a measure of the dispersion of the species in the district $\left(\mathrm{I}_{\delta}=1\right.$ : random, $\mathrm{I}_{\delta}<1$ : uniform and $\mathrm{I}_{\delta}>1$ : aggregated distributions) (Morisita, 1959a, 1959b).

For each of the abundant species, we then tested the potential relationships linking the $I_{\delta}$ value and each of the plant traits presented above separately (i.e., the seed weight, dispersal parts and seed bank longevity) using ANOVA F-tests. There was no striking evidence of multicollinearity between the tested variables.

\section{Results}

\subsection{Community level}

The inventories of the 1474 patches indicated that there was a total of 117 species in 2014, and 35 were insect-pollinated species. The species richness per patch varied from 0 to 19 , and the NIPS varied from 0 to 7 . On average, each patch hosted 4.80 plant species and 1.19 insect-pollinated species.

\subsubsection{District level}

For the species richness, our GAM results showed that the distance to the Seine River, Bercy Park and the Lyon and Bercy railway stations had quadratic effects, and for NIPS, the distance to Bercy Park and to the railway stations had quadratic effects. Globally, the species richness increased with the distance from Vincennes Wood (Fig. 3A) and decreased with the distance from the Lyon and Bercy railways (Fig. 3B) and Bercy Park (Fig. 3C). The distance to the Seine River did not show a significant effect on the species richness. For the insect-pollinated species, there were more NIPS in the neighborhood of the Seine River (Fig. 3D) and the Lyon and Bercy railway stations (Fig. 3-E). However, the number of species increased with the distance to Vincennes Wood (Fig. 3F). The effect of Bercy Park was not significant on the NIPS (Table 2).

\subsubsection{Street scale}

The species richness and NIPS appeared to be dependent on the orientation of the streets relative to the air flow created by the Seine River (Appendix A, Fig. 4A-B). In fact, parallel streets hosted significantly more species $(S=5.75$, NIPS $=3.96)$ than perpendicular ones $(S=1.79$, NIPS $=0.69)$.

Out of a total of 117 species, $40.2 \%$ produced anemochorous seeds, and animal-dispersed and barochorous species accounted for 22.2 and $28.2 \%$, respectively. The species in the other categories (endozoochorous, myrmecochorous and autochorous species) were too few to be analyzed.

Parallel streets hosted significantly more species in the mean than perpendicular ones for the 3 dissemination categories (Student's t-tests; anemochorous: $17.5 / 8.7$, p-value $=0.006$; epizoochorous: $8.4 / 4.1$, pvalue $=0.028$; barochorous: $15.3 / 9.1$, and $\mathrm{p}$-value $=0.026$ )

\subsubsection{Tree base scale}

For the species richness and the NIPS, our results for GAM showed
Table 2

Mixed effect of the tree base equipment, the mean insolation, the tree species, the presence of animal excrement, the distance from the 4 green spaces, and their one-on-one interactions on the species richness and NIPS. The degree of freedom is equal to 1 for all the studied variables.

\begin{tabular}{|c|c|c|c|c|}
\hline & \multicolumn{2}{|l|}{ Species richness } & \multicolumn{2}{|l|}{ NIPS } \\
\hline & Estimate (std error) & Effect & Estimate (std error) & Effect \\
\hline Intercept & $-0.34(0.41)$ & N.S. & $-5.16(1.91)$ & $* *$ \\
\hline Trunk & $-0.05(0.02)$ & $*$ & $-0.11(0.07)$ & * \\
\hline I(Trunk $\left.{ }^{2}\right)$ & $0.04(0.01)$ & $* *$ & $0.04(0.04)$ & N.S. \\
\hline Grill & $1.26(0.68)$ & N.S. & & N.S. \\
\hline NCSoil & $1.79(0.46)$ & $* * *$ & $4.14(2.05)$ & $* * *$ \\
\hline CSoil & $0.7(0.52)$ & N.S. & $2.73(2.23)$ & N.S. \\
\hline TCover & $0.51(0.34)$ & N.S. & $0.55(0.47)$ & N.S. \\
\hline Ailanthus & $0.34(0.25)$ & $* * *$ & $1.21(0.82)$ & $* *$ \\
\hline Carpinus & $0.97(0.85)$ & * & $4.27(2.42)$ & * \\
\hline Aesculus & $0.78(0.41)$ & * & $3.58(1.92)$ & * \\
\hline Platanus & $1.61(0.41)$ & $* * *$ & $4.84(1.91)$ & * \\
\hline Prunus & $1.06(0.49)$ & * & $3.88(2.08)$ & * \\
\hline Robinia & $0.47(0.37)$ & N.S. & $-0.42(0.41)$ & N.S. \\
\hline Tilia & $0.97(0.46)$ & * & $3.67(2.02)$ & N.S. \\
\hline Insolation & $0.01(0.01)$ & N.S. & $0.03(0.04)$ & N.S. \\
\hline Excrement & $0.56(0.07)$ & $* * *$ & $0.62(0.23)$ & $* * *$ \\
\hline Railway & $-0.04(0.06)$ & N.S. & $-0.23(0.11)$ & * \\
\hline I(Railway ${ }^{2}$ ) & $0.11(0.025)$ & $* * *$ & $0.23(0.06)$ & $* * *$ \\
\hline Park & $-0.16(0.06)$ & $* *$ & $-0.12(0.16)$ & N.S. \\
\hline $\mathrm{I}\left(\mathrm{Park}^{2}\right)$ & $-0.06(0.02)$ & * & $0.01(0.07)$ & N.S. \\
\hline River & $0.005(0.07)$ & N.S. & $-0.17(0.04)$ & $* * *$ \\
\hline I(River $\left.{ }^{2}\right)$ & $0.05(0.05)$ & N.S. & & \\
\hline Wood & $0.08(0.04)$ & $* *$ & $0.02(0.01)$ & $* *$ \\
\hline NCSoil.:Railway & & $* *$ & & $* * *$ \\
\hline
\end{tabular}

that the tree trunk diameter had quadratic effects. As expected, the results increased when the diameter of the tree trunk decreased. The results also indicated that the species richness and NIPS may depend on the equipment covering the tree bases. As expected, free bases with non compacted soil were the richest $(S=6.01$, NIPS $=1.84$ ), and the bases with total coverage were the poorest $(S=4.21, \quad$ NIPS $=0.95)$ (Fig. 5A-B). The effect of the tree species was significant for both. For example, Ailanthus altissima hosted the most species at their bases $(\mathrm{S}=6.41$, NIPS $=1.65)$. Robinia pseudoacacia had the lowest species richness and NIPS ( $\mathrm{S}=2.75$, NIPS $=0.25$ ) (Fig. $6 \mathrm{~A}-\mathrm{B})$.

According to our results, the effect of the insolation mean was not significant on the species richness and the NIPS. Tree bases with animal excrement hosted more species than the ones without it $(S=6.95$, NIPS $=2.03$ )

We found many significant interactions between some of the factors, e.g., between the equipment around the tree bases or the compaction of the soil and the distances to the Lyon and Bercy railway stations for the species richness and NIPS (Table 2).

Moreover, most of these effects explained an important proportion of the variance in the models. The $\mathrm{R}^{2}$ value for the global model with the interactions is 0.36 for the species richness and 0.24 for the NIPS.

\subsection{Distribution of the abundant species according to the district characteristics, tree base, and biological traits of the species}

Among the 117 species recorded in 2014, 28 were considered abundant (i.e., 24\%) because they were present in at least 50 tree bases. Fourteen of these species were particularly abundant (the number of observations was higher than 100) as follows: Chenopodium album L., Plantago major L., Senecio vulgaris L., Lactuca serriola L., Polygonum aviculare L., Matricaria recutita (L.) Rauschert, Stellaria media (L.) Vill., Sisymbrium irio L., Capsella bursa-pastoris (L.) Medik., Sonchus oleraceus L., Hordeum murinum L., Taraxacum campylodes G. E. Haglund and Conyza canadensis (L.) Cronquist. The most abundant was Poa annua L., which was observed in 1175 tree bases. 

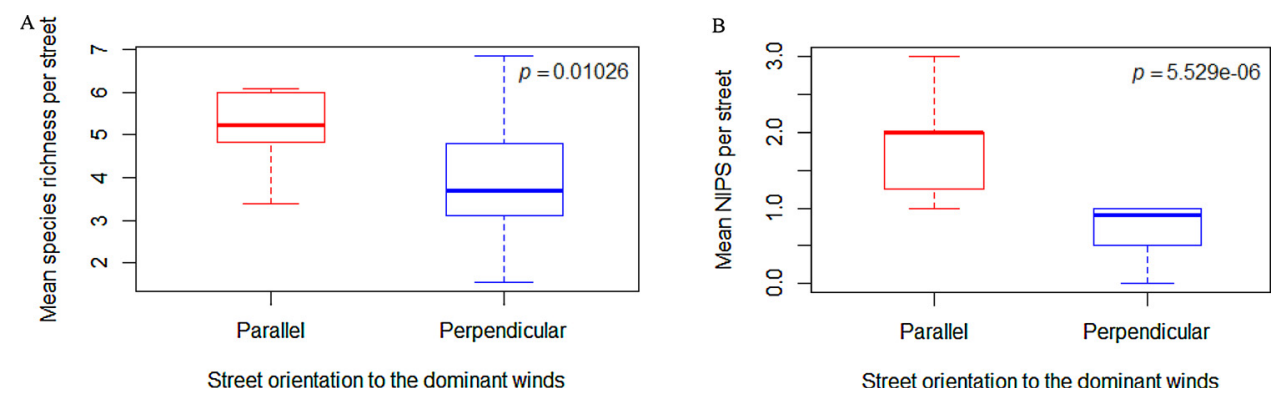

Fig. 4. Box plot of (A) the mean species richness and (B) the mean NIPS per street according to the orientation of the streets relative to the dominant winds.

\subsubsection{Species distribution according to the district characteristics}

Our results regarding the effects of the smallest Euclidean distance from each the green spaces on the presence/absence of the most abundant species are presented in Table 3, which shows the species that were mostly growing near or far from the green spaces. Certain species appeared to be distributed independently of any green spaces.

\subsubsection{Species distribution according to the tree base characteristics}

The positive or negative effects of the equipment at the tree base, the tree species and the mean insolation on the presence of the most abundant species are presented in Table 4. Certain plants appear to be able to grow regardless of the equipment and the soil compaction. We found that the presence of certain plants was dependent on the species of the trees under which they grew. The results of GLMs associated with the negative binomial error distribution showed that the presence of animal excrement had a significant positive effect on the presence of the 28 abundant species.

For each species and each variable, there is an estimate with the standard error and a p-value presented in Appendix B. The magnitude of $\mathrm{R}^{2} \mathrm{c}$, which describes the proportion of variance explained by both the fixed effects and the random factor on the presence of each abundant species, is given in Table 1. A high amount of this variance is explained by the random (i.e., the street) effect, as the conditional $R^{2}$ is higher than the marginal $\mathrm{R}^{2}$ for all the species.

\subsubsection{Species distribution according to their biological characteristics}

The Simpson's index of diversity presented in the material and methods section was used to classify the 28 abundant species according to their degree of aggregation among the patches of the district. The most widespread species, Poa annua, had an $\mathrm{I}_{\delta}$ value of 0.7 , and the most aggregated species, Cerastium glomeratum, had an $\mathrm{I}_{\delta}$ of 4.35 (Table 1).

We tested the correlation between the $\mathrm{I}_{\delta}$ value and three seed characteristics to try to explain the status of the dispersed or aggregated species (Table 1). First, we did not observe a correlation between the seed weight (Fig. 7A) or the presence or absence of dispersal devices on the seeds or fruits (Fig. 7B) and the $\mathrm{I}_{\delta}$. However, a strong relationship was observed between the seed longevity in the soil bank and the distribution of the species (Fig. 7C). The transient species are less dispersed than the species with a persistent seed bank.

\section{Discussion}

The data from the intensive inventory performed in May and June 2014 were used to list all of the species growing at the bases of all the urban trees of a district in Paris. The flora was rather rich (117 species
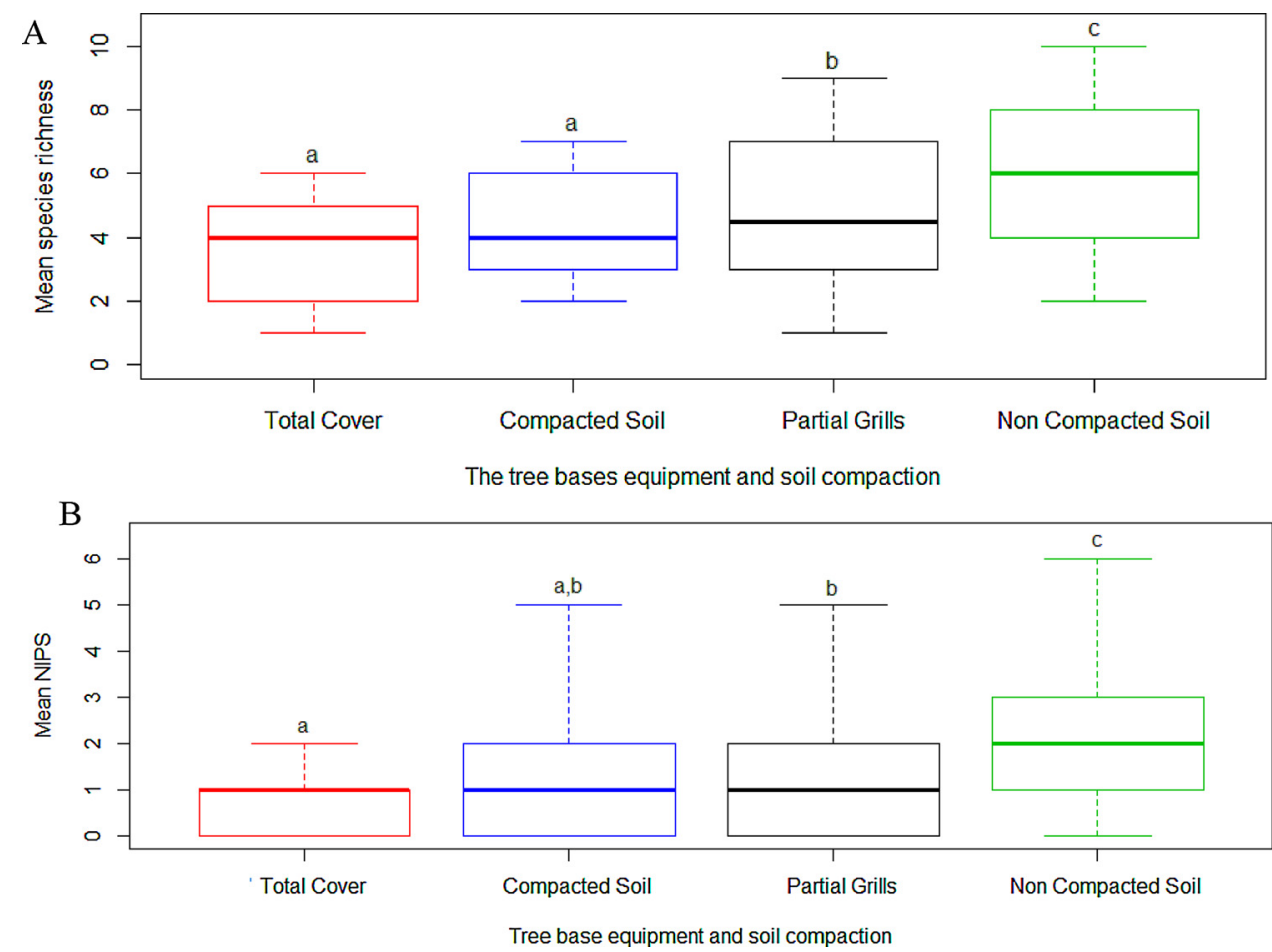

Fig. 5. Effect of the equipment that might cover the tree bases on (A) the mean species richness and (B) the mean NIPS, with letters identifying groups that significantly differ from one another according to Tukey's post hoc test. 


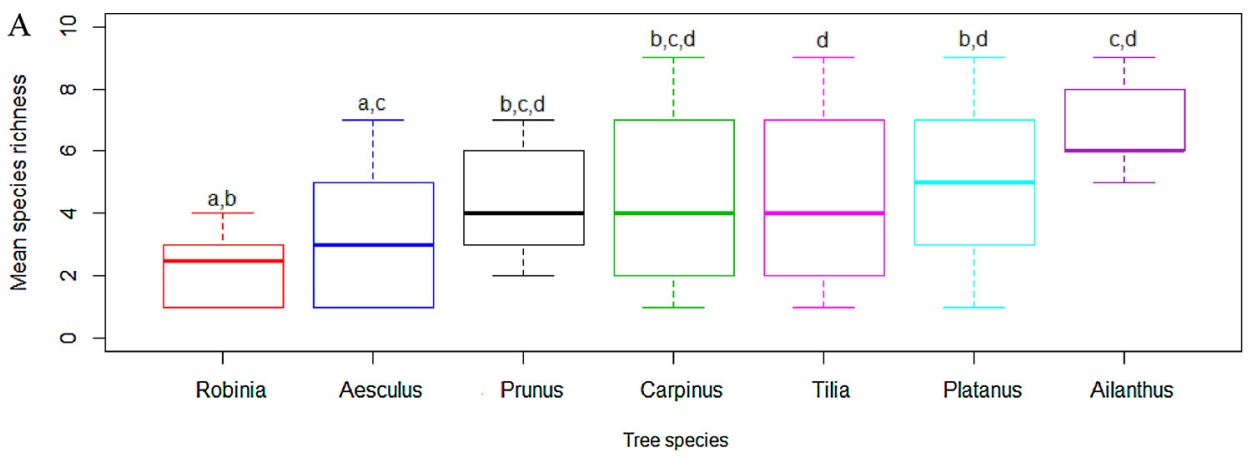

Fig. 6. Effect of the tree species on (A) the mean species richness of the communities in the patches and (B) the mean NIPS (Tukey's HSD post hoc test).

The urban tree species are Platanus $\mathrm{x}$ hispanica Miller ex Münchh., Ailanthus altissima (Mill.) Swingle, Prunus armeniaca L., Tilia cordata Mill, Aesculus hippocastanum L., Carpinus betulus L., and Robinia pseudoacacia L.

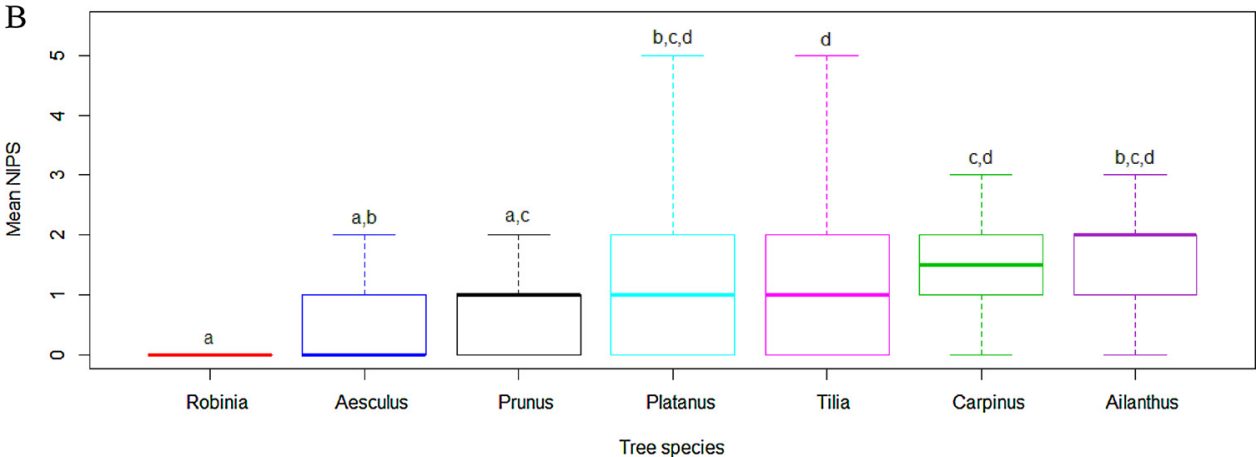

Table 3

The influence of the smallest Euclidean distance from each of green spaces on the presence/absence of each of the 28 abundant species. The pictograms have the following meanings: distance to Lyon and Bercy railway stations/ * *: Distance to Bercy Park/ $\approx$ : Distance to the Seine River/ $\int_{1}$ : Distance to Vincennes Wood.

\begin{tabular}{|c|c|c|c|c|}
\hline Species & $\ldots$ & & & \\
\hline Conyza canadensis & & & & Far \\
\hline Matricaria recutita & Far & & Near & \\
\hline Taraxacum campylodes & Far & & Near & \\
\hline Picris echioides & Far & & & \\
\hline Chenopodium album & Near & & & \\
\hline Stellaria media & Near & & & \\
\hline Senecio inaequidens & Near & Near & & \\
\hline Polygonum aviculare & Near & Near & Far & \\
\hline Cirsium arvense & & Far & Near & Near \\
\hline Plantago lanceolata & & Far & & Near \\
\hline Lactuca serriola & & Near & Far & Far \\
\hline Plantago major & & Near & & \\
\hline Picris hieracioides & & Near & Near & Near \\
\hline Sisymbrium irio & & Near & Far & Far \\
\hline Veronica persica & & & Near & \\
\hline Veronica arvensis & & & Near & \\
\hline Hordeum murinum & & & & Near \\
\hline Geranium molle & & & & Near \\
\hline
\end{tabular}

for a cumulative surface of approximately $0.25 \mathrm{ha}$ ) and abundant despite the equipment that was occasionally placed on the ground to prevent vegetation growth, tree damage and pressure imposed by trampling pedestrians (Kutiel and Zhevelev, 2001) when compared, for example, to data given by (Wittig and Becker, 2010), i.e., an average of 81 spontaneous species growing in the European cities of London, Paris, Hamburg, Copenhagen, Berlin, Vienna and Warsaw around their urban street trees.

\subsection{Community level}

Differences were observed in the species richness and NIPS at the
Table 4

The positive or negative effect of (1) the soil compaction, (2) the tree base equipment, (3) the tree species, and (4) the natural logarithm of the solar radiation on the presence/absence of the 28 abundant species. The pictograms have the following meanings: compacted soil; : Ailanthus altissima (Mill.) Swingle; Aesculus hippocastanum L.; : Carpinus betulus L.; and the natural logarithm of the mean insolation.

\begin{tabular}{|c|c|c|c|c|c|c|c|}
\hline Species & & & & है & 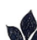 & & \\
\hline Parietaria judaica & + & - & & & & + & \\
\hline Plantago lanceolata & + & & & & & & - \\
\hline Picris echioides & + & + & & & & & \\
\hline Lactuca serriola & + & & & + & + & & \\
\hline Matricaria recutita & + & & & + & & & \\
\hline Senecio inaequidens & + & + & & & & & \\
\hline Polygonum aviculare & + & - & & + & & + & - \\
\hline Hordeum murinum & + & - & & + & & & - \\
\hline Sisymbrium irio & + & - & & & & + & + \\
\hline Sonchus oleraceus & + & + & & & & & \\
\hline Taraxacum campylodes & + & & & & + & & \\
\hline Conyza canadensis & & + & + & & + & & \\
\hline Geranium molle & & & + & & & & \\
\hline Capsella bursapastoris & & - & & & & & \\
\hline Plantago major & & & + & & & & \\
\hline Chenopodium album & & & & + & + & & - \\
\hline Cirsium arvense & & & & & & & - \\
\hline Senecio vulgaris & & & & & & + & \\
\hline Sonchus asper & & & & & & & + \\
\hline Lolium perenne & & & & & & + & \\
\hline
\end{tabular}

bases of the tree species according to various district, street and tree base characteristics.

\subsubsection{District level}

Our results showed that the effects of the green spaces such as the railways, Vincennes Wood and Bercy Park on the species richness were significant. Except for Vincennes Wood, which seems to host fewer species in its neighborhood, large green areas are surrounded by rich 


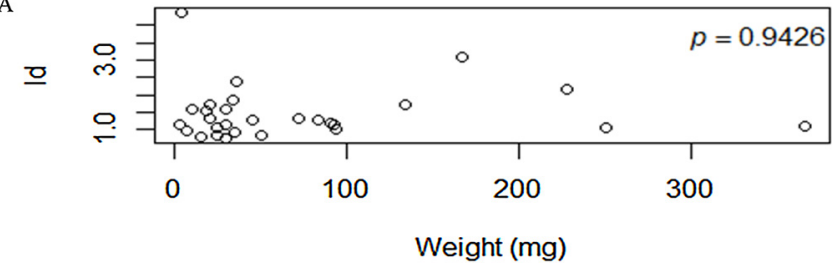

B

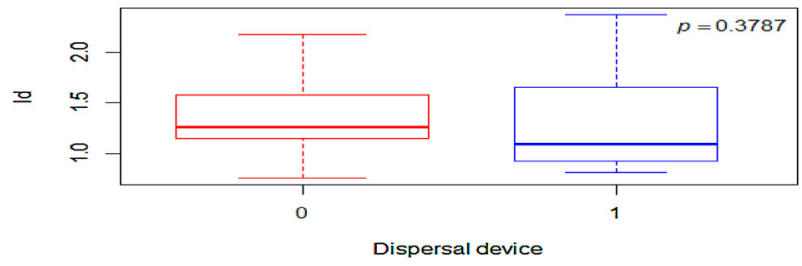

$\mathrm{C}$

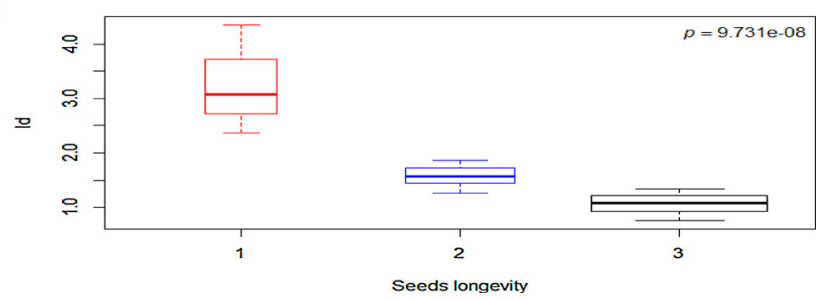

Fig. 7. Relationships among the characteristics of the seeds: A. Weight of 100 seeds (in $\mathrm{mg}$ ), B. presence (code 1 ) or absence (code 0 ) of a seed dispersal part (pappus, wing, etc.), C. seed longevity category (1, low; 2, intermediate; and 3, long) and species dispersal index (I8, (Morisita, 1959a, 1959b)).*.

tree bases because they play the role of population "sources" for the large number of species around them. According to Pauleit and Duhme, (2000) and Whitford et al. (2001), close links exist between urban land cover spatial structure (i.e. configuration types: built-up areas and open green spaces (parks, gardens, forests, woodlands, railway fallow lands) and the species richness. Open green spaces, emphasizing a mosaic of habitat patches, may contribute to improve biodiversity supply in urban environments and have a positive impact on species richness in neighborhood patches, whereas building sites in the neighborhood seemed to have negative influence. The influence of surrounding green spaces on urban biodiversity was shown to operate in a radius of $200 \mathrm{~m}$ (Muratet et al., 2007). This suggests that these spaces could be considered as main reservoirs for local urban biodiversity and might have a significant positive impact on surrounding floristic composition and species richness. In the same way, we showed that the Lyon and Bercy railway stations and the Bercy park, within a radius of $100 \mathrm{~m}$ and $400 \mathrm{~m}$ respectively, increased the floristic diversity of patches (Fig. 3B-C). For the NIPS, the effects of the bank of the Seine River and the Lyon and Bercy railway stations were significant. Around the Seine River, we found more species that were pollinated by insects. This result could be explained by the need for the insects to forage near wet zones. Next to the Lyon and Bercy railway stations, we also found more entomogamous species. We hypothesize that there could be many plants that are brought by trains from suburb. Actually, suburban zones are often characterized by abundant floral resources and high and variable pollinator densities (Hinners et al., 2012) that could be transported by train as they are by cars (Von Der Lippe and Kowarik, 2007).

\subsubsection{Street scale}

Because it constitutes a corridor for the wind, the Seine River directs air flows in its direction (Bozonnet et al., 2006). Our result showed that the species richness and NIPS were dependent on the street orientation to the Seine River, whereas these streets showed no differences in pedestrian frequency and traffic. Tree bases located in streets parallel to the Seine River hosted more species than those in perpendicular streets, which suggested that the air flows induced by the river could effectively transport a number of different species in its direction into the district. The seeds, especially the anemochorous ones, could use the lanes formed by the buildings lining the parallel streets but could be stopped by the buildings bordering the perpendicular streets. This result is in accordance with Johansson et al. (1996) which revealed that wind disperses seeds along river corridors thanks to the air flows induced by the river and thus could explain the species distribution patterns we observed. It also joins the study of Barcala and Meseguer (2007), which showed that buildings could play a windbreak function, reducing crosswind effects on train's slipstream and thus yielding a good seed retention system.

\subsubsection{Tree base level}

The structure of the equipment (partial grills and total covers) that was eventually covering the soil of the tree base and the place taken by the trunks of the trees had an influence on the richness of the flora. Clearly, any decrease in free space for vegetation (by grid or trunk) led to a reduction in the number of species at the tree bases. Our results indicated that the species richness was greater in patches with young plantations. It is likely that if the age of the tree plantation influences the number of species per patch, then the influence is partly due to the trunk diameters being so large that they significantly reduce the patch area for other plant growth (Maurel, 2010). It could also be due to the supply of seeds in the soil brought with the young tree at the stage of its transplantation. Concerning the strong effect of compaction that we obtained in our study, this result is consistent with some previous studies showing that it leads to reductions in soil porosity and infiltration (Monti and Mackintosh, 1979), reduces the diversity and abundance of plant species (Liddle, 1996), alters growth forms (Bayfield et al., 1981), and changes the vegetation cover, structure and productivity (Forbes et al., 2005).

The tree species also influenced the richness and NIPS of the communities. Allelopathy, i.e., the production of chemical compounds (Rice, 2012) that lead to the germination or growth inhibition of other species, is a mechanism that has been described for a long time (Molisch, 1937; Rice, 1979; Catalán et al., 2013). Allelopathy is certainly used by some urban trees such as Robinia pseudoacacia, whose leaves contain robinetin, myricetin and quercetin (Nasir et al., 2005), and it inhibits shoot and root growth. Al Naib and Rice (1971) explained the failure of herbaceous species to grow under the Platanus canopy and in areas with an accumulation of fallen leaves, which was not caused by low minerals, water or light contents but rather by the chemical inhibitors produced by these trees. However, if Robinia pseudoacacia hosts the fewest species at its base, then allelopathy does not appear to be a driving factor underlying the number of species surrounding Ailanthus and Platanus. Note that there is no accumulation of leaves at the base of the alignment trees because the technical services remove them with leaf blowers as soon as they fall on the pavement.

Concerning the impact of the light as a factor that influences the richness of the communities, this study showed that the potential impact of the solar light received by each tree base throughout the district on the species richness and NIPS was not significant. This result is not consistent with studies that demonstrated the role of the luminosity on the quality of communities as an environmental variable driving the plant species composition (Godefroid et al., 2007; Politi Bertoncini et al., 2012). Nevertheless, if the species richness and NIPS remain the same, regardless of the light, the list of species may be different between shaded and lit parts of the streets.

Our results showed that, compared other trees, trees with dog excrement hosted the most species at their bases. According to Bloor et al. (2012), animal excrement provides soil organic matter and nutrients to the plants and has a positive effect on the surrounding plant growth. In Paris, dog excrement is rarely picked up by dog owners when left in tree bases. Moreover, the presence of visible excrement also certainly indicates the presence of urine, which is a potential source of nitrogen. Thus, the excrement degrades on the surface of the soil and releases the 
nutrients it contains, which could have a fertilizing effect. Even if the relationships between fertilizers and species richness are not clear (Politi Bertoncini et al., 2012), the effect is potentially positive for a large portion of urban plants because they are relatively well-adapted to rich, polluted soils, which is one of the filters we mentioned above (Diaz et al., 1998; Lortie et al., 2004).

In addition to the long lists of simple effects highlighted by our results, many interactions are also significant. Their interpretation is often quite complex. For example, it appears that an interaction effect on the species richness and NIPS was found between the compaction of the soil and the distance to the railways. This finding seems to show that next to the railways, the tree bases with non compacted soil were richer than those at more than $100 \mathrm{~m}$, perhaps because of the seeds brought by the trains (Penone et al., 2012).

The last result that should be noted is the strong street effect shown by this study. Surely, the combination of several factors leads to the particularity of each street (environmental characteristics, treatments by technical services, frequency of pedestrians, animals and vehicles, etc.). It is also possible that the community of tree bases arose randomly from each green space and leads to original communities according to Hubbell's theory (2001).

\subsection{Distribution of the species according to the district and tree base characteristics and their biological traits}

\subsubsection{Abundant species according to the district and tree base characteristics}

The Lyon and Bercy railway stations represent an important amount of surface area and unoccupied zones that are occasionally left fallow, and combined with the public Bercy Park, they present an area of 14 ha; thus, these areas may represent the source of the plant populations growing in the tree bases for each of the abundant species. The Seine River is the third-longest river in France. Because of its inextricable connection to Paris, the river's gently flowing waterway could capture the seeds of certain plants along its length (approximately 485 miles/ $780 \mathrm{~km}$ ) and deposit the plants on the banks of the river. The largest public park in the city, Vincennes Wood, encompasses a total area of 995 ha (2459 acres) and could also be considered a potential seed source. These seeds could be transported by long-distance dispersal in mud stuck to shoes or on car tires from the stations or from the park to the tree bases of adjacent streets (Nathan et al., 2008). Our general inventory of the flora of Bercy Park revealed the presence of several species (including species found next to the park), such as Lactuca serriola, Senecio inaequidens and Sisymbrium irio. For the Lyon and Bercy railway stations, the species with the highest abundance were Chenopodium album and Senecio inaequidens. The species found in the Vincennes Wood neighborhood were Capsella bursa-pastoris, Geranium molle, Cirsium arvense, Veronica arvensis, Picris hieracioides and Plantago lanceolata. Finally, on the bank of the Seine River, we found the following species to be abundant: Cirsium arvense, Picris hieracioides, Plantago lanceolata, Taraxacum campylodes, Torilis japonica and Veronica arvensis.

In total, covering the tree bases prevented plant growth. The presence of partial grills reduced the surface for plant growth but prevented soil compaction, thus favoring certain species. For example, Plantago major appeared to be especially able to grow in compacted soils as previously observed by Engelaar et al. (1993).

We also highlighted the abundant species that grew better in light and open areas. The species we found primarily in tree bases lit by the sun, including Sonchus oleraceus, Sisymbrium irio, and Hordeum murinum, were considered heliophytic according to Julve's classification (Julve, 1998). We believe that their dependence on the light is stronger than it is for other species that were also designated by Julve as heliophytic but were found less systematically in lit patches. Cirsium arvense, Plantago lanceolata, Chenopodium album and Polygonum aviculare were found in the shaded tree bases where they could surely find more moisture, even if there is no evidence that shade and moisture are correlated.

The average annual precipitation in Paris is $664 \mathrm{~mm}$ (Wittig and Becker, 2010) and irrigation by the Paris technical services occurs frequently. For example, irrigation occurs during the pavement cleanings that are performed with the tanker trucks that spray water at high pressure onto the asphalt-covered parts of the sidewalks and indirectly waters the tree bases. Therefore, for herbaceous species, the amount of water is more than acceptable and sufficient to water them (Galmés et al., 2007).

The species of trees planted in the streets could also constitute strong filters for certain plant species. As previously explained, this result was clearly related to the allelopathic effects on the herbaceous species of the tree base communities, which varied according to the species' tolerance to the extracts from the litter. Moreover, certain annual plants such as Chenopodium album (mostly found under Aesculus hippocastanum and Ailanthus altissima) are known to use allelopathic chemicals to release their seeds from dormancy (Baldwin and Preston, 1999).

\subsubsection{Abundant species according to their biological traits}

We used an index describing the species distribution to classify the species on a continuum from very aggregated to very dispersed species. Before choosing the $I_{\delta}$ value (following Morisita, 1959a, 1959b and Simpson, 1949), we tested other indices. The first index tested here was the species distribution index (SDI), which represents the coefficient of variation for the average abundance among the considered streets. The second index was the logit of the proportion of tree bases occupied by a specific species in each of the 26 streets (Thomsen et al., 1991; Manel et al., 2002). We found that the three indices were strongly correlated with the species abundance. Nevertheless, the selected index was not influenced by strong differences in the number of tree bases among streets when the others were.

Contrary to our expectations, the distribution of species was not correlated with the weight of their seeds or the presence of a seed dispersal part that could influence their dispersal capacity. We hypothesized that seeds carrying dispersal parts or seeds that were light would be distributed over a greater distance than the other seeds. Hurka and Haase (1982) showed that certain light seeds, even those without a dispersal part, could be carried by the wind over long distances or via ingestion by vertebrate animals (mostly birds and mammals) by endozoochory (Corlett, 1998). Nevertheless, those two traits were not correlated to a more widespread distribution of the species. The result could be explained by the following two hypotheses: (1) all seed types, light or very light and with or without dispersal devices, have the same potential to be spread by human activity because seeds can be transported in mud stuck to shoes or car tires (Sukopp, 2004; Von Der Lippe and Kowarik, 2007), and/or (2) other factors may be involved in plant dispersal throughout an urban landscape, e.g., the seed longevity in the soil bank. In actuality, this trait could be the primary characteristic influencing the distribution of the species among the tree bases. Species with a persistent seed bank can form remnant populations (Eriksson, 1996), which enables them to bridge periods of unfavorable environmental conditions. This result is consistent with the observations described in Bossuyt and Hermy (2003), who determined the potential role of persistent soil seedbanks in restoring plant communities (Bossuyt and Hermy, 2003; Piessens et al., 2005). The species of long-term persistent seeds are often ruderal or competitive species, and they are typical of disturbed sites. They can survive for a long period in the soil and colonize the newly established community by seed dispersal or through the germination of seeds buried in the soil seedbank and could thus be dispersed more extensively throughout the district.

We also tested the correlation that could exist between the species life span (annual and perennial plants) and Simpson's index I $\delta$, but we observed no significant relationship. This result suggests that the seed 
bank primarily influences the plant distribution. Plants that can restart from the roots do not seem to be favored, and thus, we believe that they are removed by weeding.

Through all these results, we have highlighted that the management by technical services of the tree bases may represent a major filter for plant species. These services regularly remove a large part of the vegetative tissues of plants growing at the bases of the trees (once a year), sparing only propagules such as seeds and primarily favoring species that are able to disperse and to persist under the shape of seeds in the soil. The advantage could be all the more important in helping the seeds to survive after production.

\section{Conclusions}

Our study showed how small patches such as tree bases in the urban matrix can be habitats and corridors, likely linking urban green areas.

Our results demonstrated that species that were adapted for growth at the bases of urban trees in cities were influenced by different factors. First, environmental filters selected for the best-adapted traits (e.g., longevity in the soil bank and adaptation to fertilizers). The geographical structure of the district, the presence of certain green spaces and streets and the weeding and watering of the vegetation could impact the species constituting these plant communities. In certain cities, the tree bases cover large cumulative areas and host a large number of species. Thus, they certainly play an ecological role and actively participate in the development of biodiversity (Flink and Searns, 1993; Jim, 2004; Kong et al., 2010).

The results of our study can provide insights into each urban actor regarding the optimal methods of structuring the districts and streets and managing impervious surfaces to ensure that the best practices are adopted for biodiversity preservation.

From our results, we deduce the following:

- To promote urban biodiversity, it is recommended to protect tree bases from trampling, e.g., by installing small barriers.

- Unless other positive effects are expected (e.g. shading and evapotranspiration effects; filtering air particles; canopy and habitat for wildlife; aesthetics effects), we propose avoiding the use of certain tree species for alignments, i.e., Robinia pseudoacacia L., Aesculus hippocastanum L. and Prunus armeniaca L., all of which hosted the fewest species at their bases.

- We encourage cities to arrange large tree bases $\left(>4 \mathrm{~m}^{2}\right)$ so that the growth of the trunks does not completely encroach on spontaneous plants.

- In contrast to the instructions given to dog owners, it is suggested to leave dog excrement at the tree bases to enhance species richness.

Furthermore, we propose multiplying the number of large urban green spaces that could serve as reservoirs for biodiversity. In planting more alignment trees at sidewalks, which are fed by the seeds from these parks, and in protecting them from intense practices and human destruction, better conditions are provided for spontaneous wildlife, and ecological functions should be favored. This spatial planning strategy should be adopted to provide the best green space configuration aimed at the sustainable greening of compacted cities.

\section{Funding sources}

This work was supported by ANR (Agence Nationale de la Recherche) ECOVILLE [ANR 14 CE22-0021], Agence Universitaire de la Francophonie [2015LBY3], and Eiffel funding </GS3 > [895175F] http://www.campusfrance.org/fr/eiffel.

\section{Acknowledgments}

We wish to thank Amélie Barthel, Lise Ropars, Abdoul-Fatahou M'chindra and Baco Said-Allaoui, who performed the floristic survey in 2014 during their internship at the National Museum of Natural History in Paris. We give special thanks to everyone who helped and contributed to this study. We particularly thank Noëlie Maurel for her contribution during her thesis. We are also grateful to the editors of American Journal Experts for their language revisions.

Appendix A. Names of the streets, numbers of tree bases per street and orientation relative to the dominant winds and the tree species

\begin{tabular}{|c|c|c|c|c|}
\hline Street abbreviation & Street names & Number of tree bases & Orientation relative to the predominant winds & Tree species \\
\hline BARO & Baron le Roy & 62 & Parallel & Platanus \\
\hline BATA & Bataillon du Pacifique & 31 & Perpendicular & Ailanthus \\
\hline BERC & boulevard de Bercy & 126 & Parallel & Aesculus \\
\hline BERY & boulevard de Bercy & 99 & Perpendicular & Tilia \\
\hline BOss & Charles Bossut & 6 & Perpendicular & Prunus \\
\hline BOUT & Jean Bouton & 11 & Parallel & Tilia \\
\hline CHAR & Charenton & 144 & Parallel & Platanus \\
\hline CORB & Corbineau & 16 & Perpendicular & Robinia \\
\hline CORI & Coriolis & 8 & Parallel & Platanus \\
\hline DAUM & Daumesnil & 186 & Parallel & Platanus \\
\hline DIJO & Dijon & 10 & Perpendicular & Platanus \\
\hline ERAR & Erard & 16 & Perpendicular & Prunus \\
\hline GERT & Gerty Archimède & 8 & Perpendicular & Ailanthus \\
\hline KESS & Joseph Kessel & 69 & Perpendicular & Platanus \\
\hline LACH & Lachambeaudie & 31 & Perpendicular & Platanus \\
\hline MONT & Montgallet & 52 & Perpendicular & Prunus \\
\hline POMM & Pommard & 39 & Parallel & Tilia \\
\hline PROU & Proudhon & 5 & Perpendicular & Prunus \\
\hline RAMB & Rambouillet & 7 & Perpendicular & Prunus \\
\hline RAPE & Quai de la Rapée & 97 & Parallel & Platanus \\
\hline RBER & Bercy & 136 & Parallel & Tilia \\
\hline REUI & Reuilly & 145 & Parallel & Platanus \\
\hline TAIN & Taine & 62 & Perpendicular & Tilia \\
\hline TERR & Terroirs de France & 45 & Perpendicular & Platanus \\
\hline
\end{tabular}




$\begin{array}{llll}\text { VANG } & \text { Van Gogh } & 15 & \text { Perpendicular } \\ \text { VILL } & \text { Villiot } & 48 & \text { Perpendicular }\end{array}$

Appendix B. Mixed effect on the abundant species by the tree base equipment, the natural logarithm of the mean insolation, the presence animal excrement, the tree species and the distance from the 4 green spaces. The degree of freedom is equal to 1 for all studied variables

\begin{tabular}{|c|c|c|c|c|}
\hline & \multicolumn{2}{|l|}{ Cerastium glomeratum } & \multicolumn{2}{|l|}{ Plantago lanceolata } \\
\hline & Estimate (std error) & Effect & Estimate (std error) & Effect \\
\hline Grill & $0.93(0.7)$ & N.S. & $-0.37(0.2)$ & N.S. \\
\hline NCSoil & $-0.61(1.3)$ & N.S. & $1.59(0.06)$ & $* *$ \\
\hline CSoil & $-0.95(1.7)$ & N.S. & $0.07(0.7)$ & N.S. \\
\hline Carpinus & $-0.26(3.2)$ & N.S. & $-0.09(1.06)$ & N.S. \\
\hline Aesculus & $-0.51(1.1)$ & N.S. & $-0.8(1.08)$ & N.S. \\
\hline Platanus & $-0.72(1.5)$ & N.S. & $-0.21(1.6)$ & N.S. \\
\hline Prunus & $-0.04(1.8)$ & N.S. & $-0.82(1.1)$ & N.S. \\
\hline Robinia & $-0.86(2.5)$ & N.S. & $-0.7(1.6)$ & N.S. \\
\hline Tilia & $-0.55(1.9)$ & N.S. & $-0.61(0.53)$ & N.S. \\
\hline River & $0.003(0.002)$ & N.S. & $-3.5(0.01)$ & $*$ \\
\hline Wood & $0.01(0.009)$ & N.S. & $-1.9(0.85)$ & $*$ \\
\hline
\end{tabular}

\begin{tabular}{|c|c|c|c|c|}
\hline & Estimate (std error) & Effect & Estimate (std error) & Effect \\
\hline Grill & $-0.76(0.6)$ & N.S. & $-0.51(0.5)$ & N.S. \\
\hline NCSoil & $0.61(0.3)$ & N.S. & $0.067(0.5)$ & N.S. \\
\hline CSoil & $0.72(0.7)$ & N.S. & $-0.11(0.6)$ & N.S. \\
\hline Carpinus & $-0.09(1.03)$ & N.S. & $1.59(0.04)$ & $* *$ \\
\hline Aesculus & $-0.8(1.2)$ & N.S. & $0.47(1.07)$ & N.S. \\
\hline Platanus & $-0.2(1.6)$ & N.S. & $0.53(1.6)$ & N.S. \\
\hline Prunus & $-0.8(1.3)$ & N.S. & $0.58(1.1)$ & N.S. \\
\hline Robinia & $-0.67(1.5)$ & N.S. & $0.85(2.2)$ & N.S. \\
\hline Tilia & $-0.6(1.7)$ & N.S. & $0.72(1.1)$ & N.S. \\
\hline River & $-1.24(0.01)$ & $*$ & $-0.07(0.01)$ & N.S. \\
\hline Wood & $-0.95(0.07)$ & $*$ & $-1.15(0.88)$ & N.S. \\
\hline
\end{tabular}

\begin{tabular}{lllll}
\hline & \multicolumn{2}{l}{ Picris echioides } & & \multicolumn{2}{c}{ Parietaria judaica } \\
\cline { 2 - 3 } & Estimate (std error) & Effect & Estimate (std error) \\
\hline Intercept & $4.89(3.3)$ & N.S. & $-1.82(1.4)$ & Effect \\
Grill & $1.64(0.07)$ & $* *$ & $-1.6(0.5)$ & $1.43(0.7)$ \\
NCSoil & $1.89(0.08)$ & $* *$ & $0.03(0.7)$ & N.S. \\
CSoil & $0.75(0.4)$ & N.S. & $-1.93(0.2)$ & N.S.
\end{tabular}




\begin{tabular}{lllll} 
Ailanthus & $-0.07(0.7)$ & N.S. & $0.62(0.2)$ & $1.59(1.4)$ \\
Carpinus & $-0.87(0.8)$ & N.S. & $2.31(2.07)$ & N.S. \\
Aesculus & $-0.31(0.3)$ & N.S. & $0.53(0.68)$ & N.S. \\
Platanus & $-0.29(0.6)$ & N.S. & $0.59(0.22)$ & N.S. \\
Prunus & $-0.22(0.5)$ & N.S. & $-0.22(1.04)$ & N.S. \\
Robinia & $-0.71(0.3)$ & N.S. & $0.34(1.35)$ & N.S. \\
Tilia & $-0.02(0.7)$ & N.S. & $-0.45(0.29)$ & N.S. \\
Insolation & $-0.19(0.2)$ & N.S. & $1.15(0.03)$ & N.S. \\
Excrement & $1.16(0.03)$ & $* *$ & $-1.02(0.05)$ & N.S. \\
Railway & $1.19(0.01)$ & N.S. & $0.06(0.01)$ & N.S. \\
Park & $0.94(0.71)$ & N.S. & $-0.19(0.01)$ & $-0.32(0.89)$ \\
River & $-0.33(0.19)$ & N.S. & & \\
Wood & $-0.58(0.92)$ & & & \\
\hline
\end{tabular}

\begin{tabular}{|c|c|c|c|c|}
\hline & \multicolumn{2}{|l|}{ Torilis japonica } & \multicolumn{2}{|l|}{ Epilobium tetragonum } \\
\hline & Estimate (std error) & Effect & Estimate (std error) & Effect \\
\hline Intercept & $-2.21(1.24)$ & N.S. & $-1.9(1.61)$ & N.S. \\
\hline Grill & $-0.51(0.52)$ & N.S. & $0.35(0.52)$ & N.S. \\
\hline NCSoil & $0.27(0.59)$ & N.S. & $-0.18(0.75)$ & N.S. \\
\hline CSoil & $-0.03(0.67)$ & N.S. & $-0.38(0.7)$ & N.S. \\
\hline TCover & $-0.52(0.6)$ & N.S. & $-0.83(0.2)$ & N.S. \\
\hline Ailanthus & $0.02(0.1)$ & N.S. & $-0.98(0.2)$ & N.S. \\
\hline Carpinus & $-0.77(0.6)$ & N.S. & $1.49(0.4)$ & N.S. \\
\hline Aesculus & $0.42(0.2)$ & N.S. & $0.43(0.7)$ & N.S. \\
\hline Platanus & $0.63(0.5)$ & N.S. & $0.53(0.6)$ & N.S. \\
\hline Prunus & $0.55(0.1)$ & N.S. & $0.69(0.3)$ & N.S. \\
\hline Robinia & $-0.95(0.3)$ & N.S. & $-0.44(0.1)$ & N.S. \\
\hline Tilia & $0.53(0.24)$ & N.S. & $0.65(0.3)$ & N.S. \\
\hline Insolation & $0.23(0.20)$ & N.S. & $-0.29(0.24)$ & N.S. \\
\hline Excrement & $1.51(0.33)$ & $* *$ & $2.04(0.039)$ & $* *$ \\
\hline Railway & $0.04(0.02)$ & N.S. & $0.001(0.002)$ & N.S. \\
\hline Park & $0.01(0.01)$ & N.S. & $0.004(0.001)$ & N.S. \\
\hline River & $-1.44(0.01)$ & $*$ & $0.007(0.009)$ & N.S. \\
\hline Wood & $0.52(0.01)$ & N.S. & $0.003(0.006)$ & N.S. \\
\hline
\end{tabular}

\begin{tabular}{|c|c|c|c|c|}
\hline & \multicolumn{2}{|l|}{ Veronica persica } & \multicolumn{2}{|l|}{ Veronica arvensis } \\
\hline & Estimate (std error) & Effect & Estimate (std error) & Effect \\
\hline Intercept & $-2.04(1.1)$ & N.S. & $-3.16(1.61)$ & N.S. \\
\hline Grill & $0.04(0.54)$ & N.S. & $0.82(0.43)$ & N.S. \\
\hline NCSoil & $0.46(0.55)$ & N.S. & $0.18(0.49)$ & N.S. \\
\hline CSoil & $-0.73(0.97)$ & N.S. & $-0.11(0.7)$ & N.S. \\
\hline TCover & $-0.82(0.6)$ & N.S. & $-0.83(0.2)$ & N.S. \\
\hline Ailanthus & $0.42(0.18)$ & N.S. & $-0.18(0.2)$ & N.S. \\
\hline Carpinus & $0.51(0.43)$ & N.S. & $0.53(0.5)$ & N.S. \\
\hline Aesculus & $0.37(0.6)$ & N.S. & $0.63(0.4)$ & N.S. \\
\hline Platanus & $0.45(0.5)$ & N.S. & $0.71(0.6)$ & N.S. \\
\hline Prunus & $0.92(0.6)$ & N.S. & $0.69(0.3)$ & N.S. \\
\hline Robinia & $0.17(0.4)$ & N.S. & $-0.66(0.03)$ & N.S. \\
\hline Tilia & $0.98(0.64)$ & N.S. & $0.61(0.7)$ & N.S. \\
\hline Insolation & $-0.16(0.26)$ & N.S. & $0.82(0.32)$ & N.S. \\
\hline Excrement & $2.19(0.35)$ & $* * *$ & $2.08(0.02)$ & $* * *$ \\
\hline Railway & $0.05(0.01)$ & N.S. & $-0.2(0.01)$ & N.S. \\
\hline Park & $0.7(0.42)$ & N.S. & $0.1(0.08)$ & N.S. \\
\hline River & $-1.23(0.08)$ & $* *$ & $-1.01(0.09)$ & $* * *$ \\
\hline Wood & $-0.3(0.04)$ & N.S. & $-0.9(0.3)$ & N.S. \\
\hline
\end{tabular}




\begin{tabular}{|c|c|c|c|c|}
\hline & \multicolumn{2}{|l|}{ Chenopodium album } & \multicolumn{2}{|l|}{ Senecio vulgaris } \\
\hline & Estimate (std error) & Effect & Estimate (std error) & Effect \\
\hline Intercept & $-1.35(1.2)$ & N.S. & $-1.73(1.4)$ & N.S. \\
\hline Grill & $0.41(0.14)$ & N.S. & $-0.17(0.14)$ & N.S. \\
\hline NCSoil & $-0.56(0.53)$ & N.S. & $-0.86(0.62)$ & N.S. \\
\hline CSoil & $-0.53(0.54)$ & N.S. & $-0.19(0.68)$ & N.S. \\
\hline TCover & $-0.99(0.86)$ & N.S. & $-0.32(0.28)$ & N.S. \\
\hline Ailanthus & $1.44(0.31)$ & $* *$ & $0.68(0.41)$ & N.S. \\
\hline Carpinus & $0.64(0.53)$ & N.S. & $1.25(0.14)$ & $* *$ \\
\hline Aesculus & $2.45(0.09)$ & $* *$ & $0.31(0.12)$ & N.S. \\
\hline Platanus & $1.53(0.37)$ & N.S. & $0.29(0.23)$ & N.S. \\
\hline Prunus & $1.62(0.2)$ & N.S. & $0.26(1.11)$ & N.S. \\
\hline Robinia & $2.83(0.5)$ & N.S. & $0.41(1.31)$ & N.S. \\
\hline Tilia & $1.64(0.54)$ & N.S. & $0.42(1.36)$ & N.S. \\
\hline Insolation & $-1.72(0.21)$ & $*$ & $-0.08(0.24)$ & N.S. \\
\hline Excrement & $2.42(0.31)$ & $* *$ & $1.81(0.28)$ & $* *$ \\
\hline Railway & $-3.43(0.1)$ & $*$ & $0.07(0.01)$ & N.S. \\
\hline Park & $0.6(0.52)$ & N.S. & $-0.01(0.01)$ & N.S. \\
\hline River & $0.02(0.01)$ & N.S. & $-0.02(0.01)$ & N.S. \\
\hline Wood & $-0.39(0.27)$ & N.S. & $0.09(0.07)$ & N.S. \\
\hline
\end{tabular}

\begin{tabular}{llll}
\hline & Lactuca serriola & & Matricaria recutita \\
\cline { 2 - 4 } & Estimate (std error) & Effect & Estimate (std error) \\
\hline Intercept & $-8.88(1.8)$ & $* * *$ & $7.01(3.08)$ \\
Grill & $0.55(0.37)$ & N.S. & $0.07(0.36)$ \\
NCSoil & $1.84(0.06)$ & $* *$ & $1.27(0.003)$ \\
CSoil & $0.59(0.34)$ & N.S. & $-0.49(0.4)$ \\
TCover & $-0.89(0.9)$ & N.S. & $-0.32(0.09)$ \\
Ailanthus & $1.47(0.39)$ & $* *$ & $-0.61(0.54)$ \\
Carpinus & $0.03(0.43)$ & N.S. & $-0.21(0.5)$ \\
Aesculus & $2.45(0.06)$ & $* *$ & $-4.21(0.98)$ \\
Platanus & $0.55(0.37)$ & N.S. & $-5.42(0.93)$ \\
Prunus & $0.66(0.2)$ & N.S. & $-7.09(0.58)$ \\
Robinia & $0.81(0.5)$ & N.S. & $-0.46(0.23)$ \\
Tilia & $0.64(0.54)$ & N.S. & $-0.72(0.96)$ \\
Insolation & $0.19(0.18)$ & N.S. & $-0.35(0.16)$ \\
Excrement & $1.82(0.24)$ & N.S. & N.S. \\
Railway & $0.09(0.01)$ & $* * *$ & $2.69(0.22)$ \\
Park & $-2.49(0.08)$ & $* *$ & N.S. \\
River & $1.22(0.01)$ & $* * *$ & $0.71(0.09)$ \\
Wood & $2.25(0.05)$ & & $-1.26(0.01)$ \\
\hline & & $-0.12(0.07)$ & N.S. \\
\hline
\end{tabular}

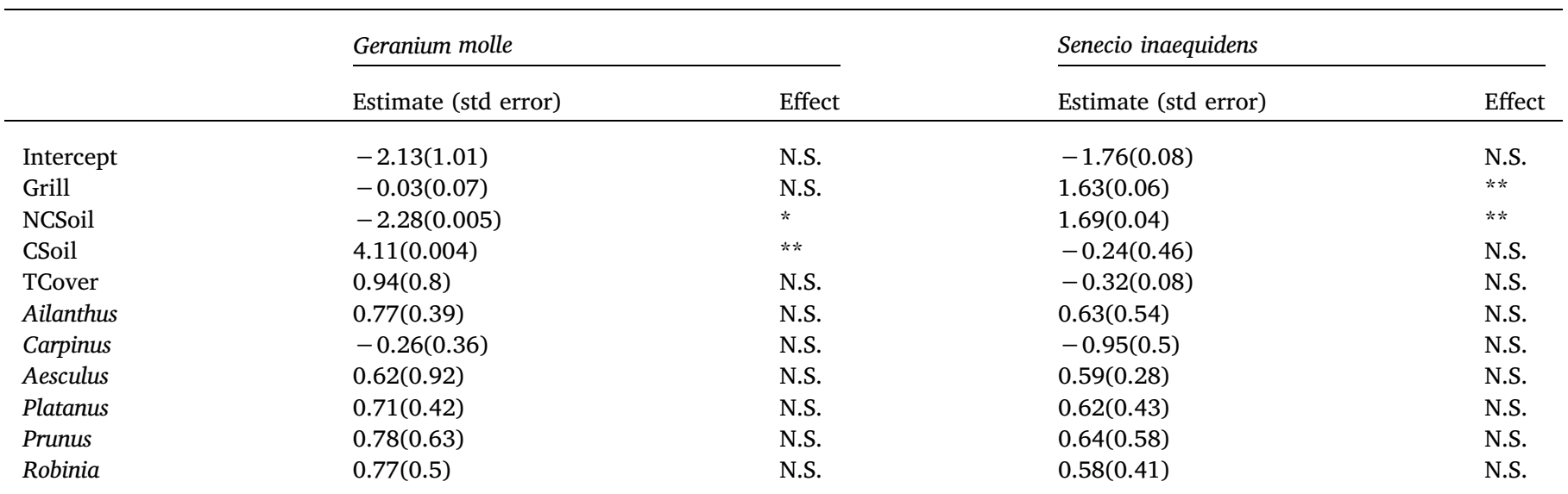




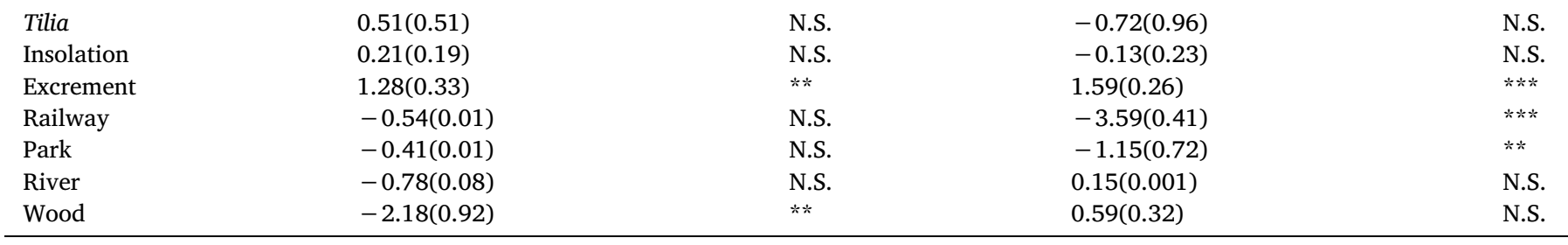

\begin{tabular}{|c|c|c|c|c|}
\hline & \multicolumn{2}{|l|}{ Capsella bursa-pastoris } & \multicolumn{2}{|l|}{ Polygonum aviculare } \\
\hline & Estimate (std error) & Effect & Estimate (std error) & Effect \\
\hline Intercept & $-2.78(2.52)$ & N.S. & $-14.12(2.11)$ & $* * *$ \\
\hline Grill & $-1.65(0.19)$ & $*$ & $-1.24(0.31)$ & $* *$ \\
\hline NCSoil & $0.27(0.22)$ & N.S. & $2.45(0.37)$ & $* *$ \\
\hline CSoil & $0.24(0.22)$ & N.S. & $0.93(0.37)$ & N.S. \\
\hline TCover & $0.46(0.41)$ & N.S. & $0.02(0.01)$ & N.S. \\
\hline Ailanthus & $0.45(2.04)$ & N.S. & $1.33(0.24)$ & $* *$ \\
\hline Carpinus & $0.73(1.46)$ & N.S. & $1.13(0.5)$ & $* *$ \\
\hline Aesculus & $0.24(0.91)$ & N.S. & $0.59(0.28)$ & N.S. \\
\hline Platanus & $0.23(0.18)$ & N.S. & $0.32(0.23)$ & N.S. \\
\hline Prunus & $-0.49(0.23)$ & N.S. & $0.21(0.18)$ & N.S. \\
\hline Robinia & $0.78(0.25)$ & N.S. & $0.49(0.41)$ & N.S. \\
\hline Tilia & $-0.045(0.1)$ & N.S. & $0.96(0.15)$ & N.S. \\
\hline Insolation & $0.28(0.13)$ & N.S. & $-3.42(0.21)$ & $*$ \\
\hline Excrement & $1.16(0.19)$ & $* * *$ & $1.89(0.22)$ & $* *$ \\
\hline Railway & $0.31(0.01)$ & N.S. & $-4.004(0.17)$ & $* * *$ \\
\hline Park & $0.89(0.07)$ & N.S. & $-3.002(0.92)$ & $* *$ \\
\hline River & $-0.82(0.01)$ & N.S. & $3.11(0.15)$ & $* *$ \\
\hline Wood & $-2.16(0.05)$ & $* *$ & $0.19(0.08)$ & N.S. \\
\hline
\end{tabular}

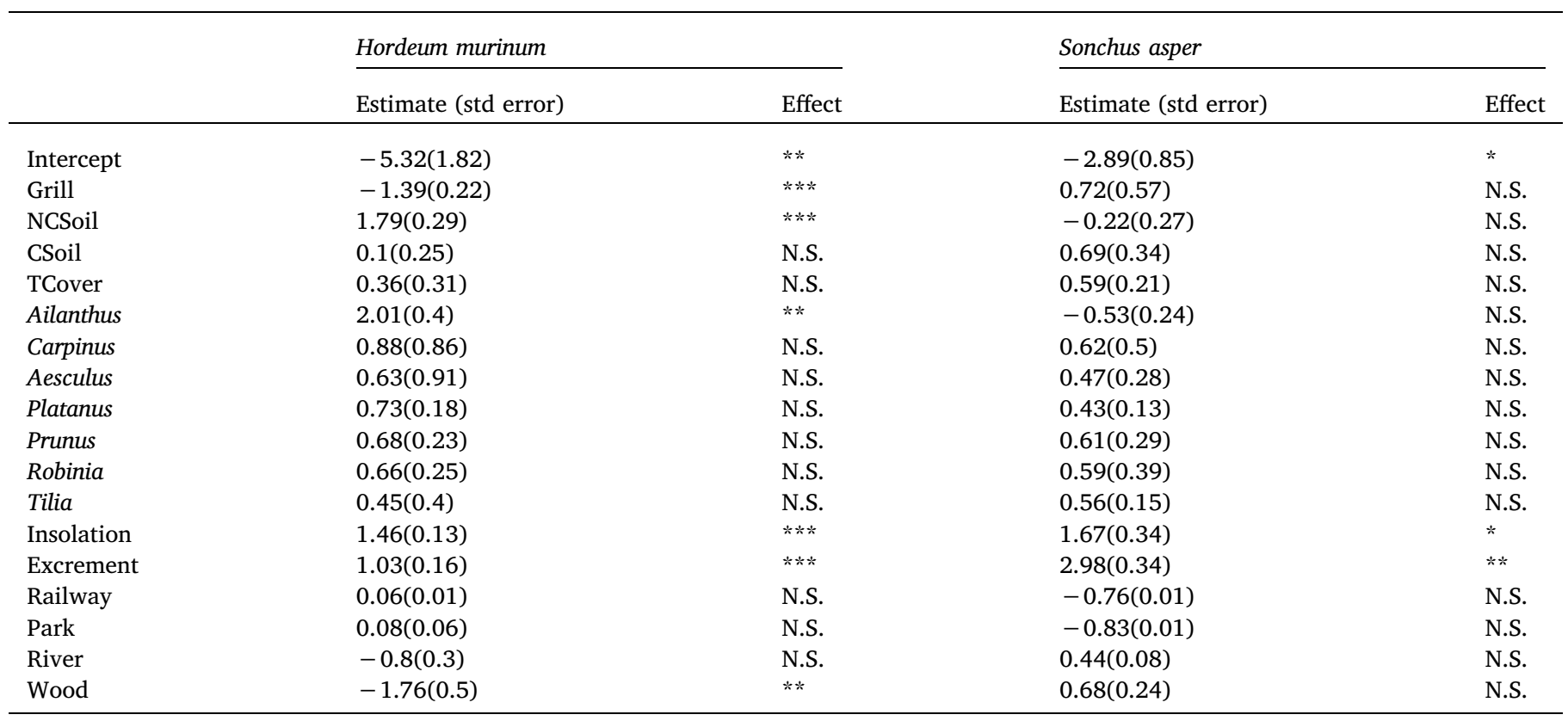

\begin{tabular}{lllll}
\hline & \multicolumn{2}{l}{ Plantago major } & & \multicolumn{2}{c}{ Picris hieracioides } \\
\cline { 2 - 3 } & Estimate (std error) & Effect & Estimate (std error) \\
\hline Intercept & $-2.08(1.81)$ & N.S. & $-3.75(0.005)$ \\
Grill & $0.79(0.22)$ & N.S. & $-0.05(0.44)$
\end{tabular}




\begin{tabular}{lllll} 
NCSoil & $-1.51(0.005)$ & $*$ & $0.16(0.12)$ & $-0.06(0.79)$ \\
CSoil & $4.16(0.004)$ & $* *$ & $0.49(0.11)$ & N.S. \\
TCover & $0.46(0.41)$ & N.S. & $0.13(0.24)$ & N.S. \\
Ailanthus & $0.65(0.61)$ & N.S. & $-0.06(0.05)$ & N.S. \\
Carpinus & $0.83(0.86)$ & N.S. & $0.69(0.18)$ & N.S. \\
Aesculus & $0.69(0.81)$ & N.S. & $0.61(0.13)$ & N.S. \\
Platanus & $0.71(0.18)$ & N.S. & $0.65(0.29)$ & N.S. \\
Prunus & $0.67(0.23)$ & N.S. & $0.84(0.39)$ & N.S. \\
Robinia & $0.23(0.25)$ & N.S. & $0.77(0.25)$ & N.S. \\
Tilia & $0.65(0.4)$ & N.S. & $-0.05(0.02)$ & $1.85(0.32)$ \\
Insolation & $-0.15(0.12)$ & N.S. & $-0.02(0.01)$ \\
Excrement & $1.62(0.24)$ & $* *$ & $-1.29(0.06)$ \\
Railway & $0.1(0.08)$ & N.S. & $-2.17(0.08)$ \\
Park & $-1.21(0.07)$ & N.S. & $-2.14(0.04)$ \\
River & $0.03(0.01)$ & N.S. & N.S. \\
Wood & $0.07(0.04)$ & & $* *$ \\
\hline
\end{tabular}

\begin{tabular}{|c|c|c|c|c|}
\hline & \multicolumn{2}{|l|}{ Sisymbrium irio } & \multicolumn{2}{|l|}{ Stellaria media } \\
\hline & Estimate (std error) & Effect & Estimate (std error) & Effect \\
\hline Intercept & $-9.92(2.12)$ & $\div * *$ & $-4.24(1.38)$ & $*$ \\
\hline Grill & $-0.62(0.28)$ & $*$ & $0.37(0.31)$ & N.S. \\
\hline NCSoil & $0.68(0.32)$ & * & $0.02(0.03)$ & N.S. \\
\hline CSoil & $-0.73(0.29)$ & $*$ & $-0.06(0.79)$ & N.S. \\
\hline TCover & $0.46(0.41)$ & N.S. & $0.58(0.41)$ & N.S. \\
\hline Ailanthus & $0.71(0.17)$ & N.S. & $0.43(0.38)$ & N.S. \\
\hline Carpinus & $4.01(0.09)$ & $* *$ & $-0.45(0.16)$ & N.S. \\
\hline Aesculus & $-0.24(0.18)$ & N.S. & $0.49(0.38)$ & N.S. \\
\hline Platanus & $0.38(0.53)$ & N.S. & $0.51(0.25)$ & N.S. \\
\hline Prunus & $0.59(0.66)$ & N.S. & $0.54(0.18)$ & N.S. \\
\hline Robinia & $-0.58(0.13)$ & N.S. & $0.42(0.32)$ & N.S. \\
\hline Tilia & $0.49(0.52)$ & N.S. & $0.42(0.25)$ & N.S. \\
\hline Insolation & $1.81(0.15)$ & $*$ & $-0.01(0.01)$ & N.S. \\
\hline Excrement & $2.95(0.18)$ & $* * *$ & $1.05(0.17)$ & $* *$ \\
\hline Railway & $-0.04(0.01)$ & N.S. & $-1.02(0.09)$ & $* *$ \\
\hline Park & $-1.49(0.49)$ & $* * *$ & $0.09(0.03)$ & N.S. \\
\hline River & $1.82(0.19)$ & $*$ & $0.78(0.02)$ & N.S. \\
\hline Wood & $3.28(0.65)$ & $* * *$ & $0.97(0.68)$ & N.S. \\
\hline
\end{tabular}

\begin{tabular}{|c|c|c|c|c|}
\hline & \multicolumn{2}{|l|}{ Sonchus oleraceus } & \multicolumn{2}{|l|}{ Taraxacum campylodes } \\
\hline & Estimate (std error) & Effect & Estimate (std error) & Effect \\
\hline Intercept & $-4.81(1.62)$ & * & $0.95(0.94)$ & N.S. \\
\hline Grill & $2.76(0.22)$ & $* * *$ & $0.33(0.21)$ & N.S. \\
\hline NCSoil & $4.71(0.26)$ & $* *$ & $1.38(0.25)$ & $* * *$ \\
\hline CSoil & $-1.57(0.25)$ & $*$ & $0.98(0.23)$ & N.S. \\
\hline TCover & $0.46(0.41)$ & N.S. & $0.19(0.47)$ & N.S. \\
\hline Ailanthus & $0.49(0.82)$ & N.S. & $-0.07(0.37)$ & N.S. \\
\hline Carpinus & $0.23(0.99)$ & N.S. & $0.67(0.16)$ & N.S. \\
\hline Aesculus & $0.48(0.21)$ & N.S. & $1.82(0.12)$ & $* *$ \\
\hline Platanus & $0.38(0.19)$ & N.S. & $0.85(0.69)$ & N.S. \\
\hline Prunus & $0.51(0.29)$ & N.S. & $0.06(0.13)$ & N.S. \\
\hline Robinia & $0.32(0.13)$ & N.S. & $-0.64(0.15)$ & N.S. \\
\hline Tilia & $0.44(0.32)$ & N.S. & $0.42(0.25)$ & N.S. \\
\hline Insolation & $0.74(0.11)$ & N.S. & $-0.15(0.17)$ & N.S. \\
\hline Excrement & $1.05(0.15)$ & $* * *$ & $1.28(0.15)$ & $* * *$ \\
\hline Railway & $-0.07(0.04)$ & N.S. & $1.01(0.07)$ & $* *$ \\
\hline Park & $0.07(0.05)$ & N.S. & $0.09(0.04)$ & N.S. \\
\hline River & $-0.09(0.06)$ & N.S. & $-2.83(0.08)$ & $* *$ \\
\hline Wood & $0.04(0.03)$ & N.S. & $-0.09(0.04)$ & N.S. \\
\hline
\end{tabular}




\begin{tabular}{|c|c|c|c|c|}
\hline & \multicolumn{2}{|l|}{ Conyza canadensis } & \multicolumn{2}{|l|}{ Poa annua } \\
\hline & Estimate (std error) & Effect & Estimate (std error) & Effect \\
\hline Intercept & $-1.71(0.49)$ & N.S. & $1.77(1.44)$ & N.S. \\
\hline Grill & $0.81(0.02)$ & $* * *$ & $0.21(0.24)$ & N.S. \\
\hline NCSoil & $-2.24(0.03)$ & $*$ & $0.01(0.02)$ & N.S. \\
\hline CSoil & $1.54(0.02)$ & * & $0.02(0.01)$ & N.S. \\
\hline TCover & $0.48(0.47)$ & N.S. & $0.19(0.47)$ & N.S. \\
\hline Ailanthus & $0.43(0.49)$ & N.S. & $-0.64(0.37)$ & N.S. \\
\hline Carpinus & $0.69(0.49)$ & N.S. & $-0.16(0.09)$ & N.S. \\
\hline Aesculus & $1.38(0.09)$ & $* *$ & $-0.15(0.12)$ & N.S. \\
\hline Platanus & $0.38(0.19)$ & N.S. & $-0.46(0.44)$ & N.S. \\
\hline Prunus & $0.25(0.17)$ & N.S. & $-0.55(0.43)$ & N.S. \\
\hline Robinia & $0.47(0.39)$ & N.S. & $-0.42(0.41)$ & N.S. \\
\hline Tilia & $0.45(0.32)$ & N.S. & $-0.52(0.44)$ & N.S. \\
\hline Insolation & $-0.37(0.14)$ & N.S. & $-0.14(0.13)$ & N.S. \\
\hline Excrement & $1.13(0.15)$ & $* *$ & $0.86(0.15)$ & $* * * *$ \\
\hline Railway & $0.02(0.03)$ & N.S. & $0.01(0.01)$ & N.S. \\
\hline Park & $0.01(0.06)$ & N.S. & $-0.08(0.07)$ & N.S. \\
\hline River & $0.09(0.08)$ & N.S. & $0.01(0.09)$ & N.S. \\
\hline Wood & $2.17(0.74)$ & $* *$ & $0.01(0.05)$ & N.S. \\
\hline
\end{tabular}

\section{References}

Al Naib, F., Rice, E.L., 1971. Allelopathic effects of Platanus occidentalis. Bull. Torrey Bot. Club 98 (2), 75. https://doi.org/10.2307/2483770.

Armstrong, R.A., 2014. When to use the Bonferroni correction. Ophthalmic Physiol. Opt. 34 (5), 502-508. https://doi.org/10.1111/opo.12131.

Baldwin, I.T., Preston, C.A., 1999. The eco-physiological complexity of plant responses to insect herbivores. Planta 208 (2), 137-145. https://doi.org/10.1007/ s004250050543.

Barcala, M.A., Meseguer, J., 2007. An experimental study of the influence of parapets on the aerodynamic loads under cross wind on a two-dimensional model of a railway vehicle on a bridge. Proc. Inst. Mech. Eng. Part F: J. Rail Rapid Transit 221 (4), 487-494. https://doi.org/10.1243/09544097JRRT53.

Barton, K., 2009. MuMIn: Multi-Model Inference. R Package Version 1.0.0. http://R Forge.r-Project.Org/Projects/Mumin/.

Bates, D., Maechler, M., Bolker, B., Walker, S., 2014. lme4: Linear Mixed-Effects Models Using Eigen and S4. R Package Version, 1 (7). pp. 1-23.

Bayfield, N.G., Urquhart, U.H., Cooper, S.M., 1981. susceptibility of four species of cladonia to disturbance by trampling in the Cairngorm Mountains, Scotland. J. Appl. Ecol. 18 (1), 303. https://doi.org/10.2307/2402497.

Besse, M.-T., 2011. Atelier Parisien d'Urbanisme. Le Monde Des Cartes 208, 11-13.

Bierwagen, B.G., 2007. Connectivity in urbanizing landscapes: the importance of habitat configuration, urban area size, and dispersal. Urban Ecosyst. 10 (1), 29-42. https:// doi.org/10.1007/s11252-006-0011-6.

Bloor, J.M.G., Jay-Robert, P., Le Morvan, A., Fleurance, G., 2012. Déjections des herbivores domestiques au pâturage: caractéristiques et rôle dans le fonctionnement des prairies. Productions Animales 25 (1), 45.

Bossuyt, B., Hermy, M., 2003. The potential of soil seedbanks in the ecological restoration of grassland and heathland communities. Belg. J. Bot. 23-34.

Bozonnet, E., Belarbi, R., Allard, F., 2006. Modelling air flows around buildings in urban environment. Presented at the International Workshop on Energy Performance and envIronmental Quality of Buildings.

Catalán, P., Vázquez-de-Aldana, B.R., de las Heras, P., Fernández-Seral, A., Pérez-Corona, M.E., 2013. Comparing the allelopathic potential of exotic and native plant species on understory plants: are exotic plants better armed? (p. 65). Presented at the Anales De Biología.

Chatterjee, S., Hadi, A.S., 2015. Regression Analysis by Example. John Wiley \& Sons.

Contassot, Y., 2008. Plan climat de Paris : la responsabilité d'une ville. Annales des Mines - Responsabilité et environnement 49 (1), 24. https://doi.org/10.3917/re.049.0024.

Corlett, R.T., 1998. Frugivory and seed dispersal by vertebrates in the Oriental (Indomalayan) Region. Biol. Rev. Camb. Philos. Soc. 73 (4), 413-448. https://doi. org/10.1017/S0006323198005234.

Diaz, S., Cabido, M., Casanoves, F., 1998. Plant functional traits and environmental filters at a regional scale. J. Veg. Sci. 9 (1), 113-122. https://doi.org/10.2307/3237229.

Engelaar, W.M.H.G., Bruggen, M.W., Hoek, W.P.M., Huyser, M.A.H., Blom, C.W.P.M. 1993. Root porosities and radial oxygen losses of Rumex and Plantago species as influenced by soil pore diameter and soil aeration. New Phytol. 125 (3), 565-574. https://doi.org/10.1111/j.1469-8137.1993.tb03904.x.

Eriksson, O., 1996. Regional dynamics of plants: a review of evidence for remnant, source-sink and metapopulations. Oikos 77 (2), 248. https://doi.org/10.2307/
3546063.

Fahrig, L., 2017. Ecological responses to habitat fragmentation Per Se. Annu. Rev. Ecol. Evol. Syst. 48 (1), 1-23. https://doi.org/10.1146/annurev-ecolsys-110316-022612.

Flink, C.A., Searns, R.M., 1993. Greenways: A Guide to Planning, Desing, and Development. Island Press.

Forbes, B., Tolvanen, A., Laine, K., Wielgolaski, F., 2005. Rates and processes of natural regeneration in disturbed habitats. Plant Ecology, Herbivory, and Human Impact in Nordic Mountain Birch Forests. Springer, pp. 193-202.

Fox, J., Weisberg, S., Adler, D., Bates, D., Baud-Bovy, G., Ellison, S., et al., 2017. Package 'car.'.

Galmés, J., Medrano, H., Flexas, J., 2007. Photosynthetic limitations in response to water stress and recovery in Mediterranean plants with different growth forms. New Phytol. 175 (1), 81-93. https://doi.org/10.1111/j.1469-8137.2007.02087.x.

Gargominy, O., Tercerie, S., Régnier, C., Ramage, T., Schoelinck, C., Dupont, P., et al., 2014. TAXREF v8. 0, référentiel taxonomique pour la France: Méthodologie, mise en oeuvre et diffusion. Rapport SPN Vol. 42.

Godefroid, S., Monbaliu, D., Koedam, N., 2007. The role of soil and microclimatic variables in the distribution patterns of urban wasteland flora in Brussels, Belgium. Landsc. Urban Plan. 80 (1-2), 45-55. https://doi.org/10.1016/j.landurbplan.2006. 06.001.

Hinners, S.J., Kearns, C.A., Wessman, C.A., 2012. Roles of scale, matrix, and native habitat in supporting a diverse suburban pollinator assemblage. Ecol. Appl. 22 (7), 1923-1935. https://doi.org/10.1890/11-1590.1.

Howe, H.F., Smallwood, J., 1982. Ecology of seed dispersal. Annu. Rev. Ecol. Syst. 13 (1), 201-228. https://doi.org/10.1146/annurev.es.13.110182.001221.

Hubbell, S.P., 2001. The Unified Neutral Theory of Biodiversity and Biogeography (MPB32)(Monographs in Population Biology). Princeton University Press.

Hurka, H., Haase, R., 1982. Seed Ecology of Capsella bursa-pastoris (Cruciferae): Dispersal Mechanism and the Soil Seed Bank1)1)Dedicated to Prof. Dr. Karl Mägdefrau on the occasion of his 75. birthday. Flora 172 (1), 35-46. https://doi.org/ 10.1016/S0367-2530(17)31309-9.

Ignatieva, M., Meurk, C.D., Newell, C., 2000. Urban biotopes: the typical and unique habitats of city environments and their natural analogues. Presented at the Urban Biodiversity and Ecology as a Basis for Holistic Planning and Design: Proceedings of a Workshop Held at Lincoln University. pp. 46-53.

INSEE, 2017. Comparateur de territoire - Commune de Paris 12e Arrondissement (75112). Retrieved from. (75112). (Accessed 12 October 17). www.insee.fr/fr/ statistiques/1405599?geo $=$ COM-75112.

Jim, C., 2004. Green-space preservation and allocation for sustainable greening of compact cities. Cities 21 (4), 311-320. https://doi.org/10.1016/j.cities.2004.04.004.

Johansson, M.E., Nilsson, C., Nilsson, E., 1996. Do rivers function as corridors for plant dispersal? J. Veg. Sci. 7 (4), 593-598. https://doi.org/10.2307/3236309.

Julve, P., 1998. Baseflor. Index botanique, écologique et chorologique de la flore de France. Institut Catholique de Lille, Lille. Retrieved from. http://perso.wanadoo.fr/ philippe.julve/catminat.htm.

Kendal, D., Williams, K.J.H., Williams, N.S.G., 2012. Plant traits link people's plant preferences to the composition of their gardens. Landsc. Urban Plan. 105 (1-2), 34-42. https://doi.org/10.1016/j.landurbplan.2011.11.023.

Kendall, M.G., 1938. A new measure of rank correlation. Biometrika 30 (1/2), 81. https:// doi.org/10.2307/2332226. 
Knapp, S., Kuehn, I., Wittig, R., Ozinga, W., Poschlod, P., Klotz, S., 2008. Urbanization causes shifts of species' trait state frequencies. Preslia 80, 375-388.

Kong, F., Yin, H., Nakagoshi, N., Zong, Y., 2010. Urban green space network development for biodiversity conservation: identification based on graph theory and gravity modeling. Landsc. Urban Plan. 95 (1-2), 16-27. https://doi.org/10.1016/j. landurbplan.2009.11.001.

Kraft, N.J.B., Godoy, O., Levine, J.M., 2015. Plant functional traits and the multidimensional nature of species coexistence. Proc. Natl. Acad. Sci. 112 (3), 797-802. https://doi.org/10.1073/pnas.1413650112.

Kühn, I., Durka, W., Klotz, S., 2004. BiolFlor: a new plant-trait database as a tool for plant invasion ecology. Divers. Distrib. 10 (5/6), 363-365.

Kutiel, P., Zhevelev, Y., 2001. Recreational use impact on soil and vegetation at picnic sites in Aleppo pine forests onMount Carmel, Israel. Isr. J. Plant Sci. 49 (1), 49-56. https://doi.org/10.1560/G2L1-8U80-5XNQ-G38C.

Lawson, E.R., 1967. Throughall and stemflow in a pine-hardwood stand in the Ouachita Mountains of Arkansas. Water Resour. Res. 3 (3), 731-735. https://doi.org/10.1029/ WR003i003p00731.

Lewis, R., 1989. Wetlands restoration/creation/enhancement terminology: suggestions for standardization. Wetland Creat. Restor.: Status Sci. 2, 3-89.

Liddle, M., 1996. Recreation and the Environment. Chapman and Hall, London.

Lortie, C.J., Brooker, R.W., Choler, P., Kikvidze, Z., Michalet, R., Pugnaire, F.I., Callaway, R.M., 2004. Rethinking plant community theory. Oikos 107 (2), 433-438. https:// doi.org/10.1111/j.0030-1299.2004.13250.x.

Lundholm, J.T., Marlin, A., 2006. Habitat origins and microhabitat preferences of urban plant species. Urban Ecosyst. 9 (3), 139-159. https://doi.org/10.1007/s11252-0068587-4.

Manel, S., Williams, H.C., Ormerod, S.J., 2002. Evaluating presence-absence models in ecology: the need to account for prevalence: presence-absence modelling. J. Appl. Ecol. 38 (5), 921-931. https://doi.org/10.1046/j.1365-2664.2001.00647.x.

Maurel, N., 2010. De l'introduction à l'invasion : les plantes exotiques en milieu urbain.

McGarigal, K., Cushman, S.A., 2002. Comparative evaluation of experimental approaches to the study of habitat fragmentation effect. Ecol. Appl. 12 (2), 335-345. https://doi. org/10.1890/1051-0761(2002)012[0335:CEOEAT]2.0.CO;2.

Molisch, H., 1937. einfluss einer pflanze auf die andere, allelopathie.

Monti, P.W., Mackintosh, E.E., 1979. Effect of camping on surface soil properties in the Boreal Forest Region of Northwestern Ontario, Canada1. Soil Sci. Soc. Am. J. 43 (5), 1024. https://doi.org/10.2136/sssaj1979.03615995004300050042x.

Morisita, M., 1959a. Measuring of the dispersion of individuals and analysis of the distributional patterns. Mem. Fac. Sci. Kyushu Univ. Ser. E Biol. 3, 65-80.

Morisita, M., 1959b. Measuring of the dispersion of individuals and analysis of the distributional patterns. Mem. Fac. Sci. Kyushu Univ. Ser. E 21 (2), 5-235.

Muratet, A., Machon, N., Jiguet, F., Moret, J., Porcher, E., 2007. The role of urban structures in the distribution of wasteland flora in the greater Paris area, France. Ecosystems 10 (4), 661. https://doi.org/10.1007/s10021-007-9047-6.

Nakagawa, S., Schielzeth, H., 2013. A general and simple method for obtaining R 2 from generalized linear mixed-effects models. Methods Ecol. Evol. 4 (2), 133-142. https:// doi.org/10.1111/j.2041-210x.2012.00261.x.

Nasir, H., Iqbal, Z., Hiradate, S., Fujii, Y., 2005. Allelopathic potential of Robinia pseudoacacia L. J. Chem. Ecol. 31 (9), 2179-2192. https://doi.org/10.1007/s10886-0056084-5.

Nathan, R., Schurr, F.M., Spiegel, O., Steinitz, O., Trakhtenbrot, A., Tsoar, A., 2008 Mechanisms of long-distance seed dispersal. Trends Ecol. Evol. 23 (11), 638-647. https://doi.org/10.1016/j.tree.2008.08.003.

Pauleit, S., Duhme, F., 2000. Assessing the environmental performance of land cover types for urban planning. Landsc. Urban Plan. 52 (1), 1-20. https://doi.org/10.1016/ S0169-2046(00)00109-2.

Pellegrini, P., Baudry, S., 2014. Streets as new places to bring together both humans and plants: examples from Paris and Montpellier (France). Soc. Cult. Geogr. 15 (8), 871-900. https://doi.org/10.1080/14649365.2014.974067.

Pellissier, V., Muratet, A., Verfaillie, F., Machon, N., 2012. Pollination success of Lotus corniculatus (L.) in an urban context. Acta Oecologica 39, 94-100. https://doi.org/ 10.1016/j.actao.2012.01.008.

Penone, C., Machon, N., Julliard, R., Le Viol, I., 2012. Do railway edges provide functional connectivity for plant communities in an urban context? Biol. Conserv. 148 (1), 126-133. https://doi.org/10.1016/j.biocon.2012.01.041.

Piessens, K., Honnay, O., Hermy, M., 2005. The role of fragment area and isolation in the conservation of heathland species. Biol. Conserv. 122 (1), 61-69. https://doi.org/10. 1016/j.biocon.2004.05.023

Politi Bertoncini, A., Machon, N., Pavoine, S., Muratet, A., 2012. Local gardening practices shape urban lawn floristic communities. Landsc. Urban Plan. 105 (1-2), 53-61. https://doi.org/10.1016/j.landurbplan.2011.11.017.

Rice, E.L., 1979. Allelopathy—an update. Bot. Rev. 45 (1), 15-109.

Rice, E.L., 2012. Allelopathy. Academic press.

Ruxton, G.D., Beauchamp, G., 2008. Time for some a priori thinking about post hoc testing. Behav. Ecol. 19 (3), 690-693. https://doi.org/10.1093/beheco/arn020.

Schmidt, K.J., Poppendieck, H.-H., Jensen, K., 2014. Effects of urban structure on plant species richness in a large European city. Urban Ecosyst. 17 (2), 427-444. https:// doi.org/10.1007/s11252-013-0319-y.

Serret, H., Raymond, R., Foltête, J.-C., Clergeau, P., Simon, L., Machon, N., 2014. Potential contributions of green spaces at business sites to the ecological network in an urban agglomeration: The case of the Ile-de-France region, France. Landsc. Urban Plan. 131, 27-35. https://doi.org/10.1016/j.landurbplan.2014.07.003.

Shwartz, A., Muratet, A., Simon, L., Julliard, R., 2013. Local and management variables outweigh landscape effects in enhancing the diversity of different taxa in a big metropolis. Biol. Conserv. 157, 285-292. https://doi.org/10.1016/j.biocon.2012.09. 009.

Simpson, E.H., 1949. Measurement of diversity. Nature 163 (4148), 688. https://doi.org/ 10.1038/163688a0.

Sukopp, H., 2004. Human-caused impact on preserved vegetation. Landsc. Urban Plann. 68 (4), 347-355. https://doi.org/10.1016/S0169-2046(03)00152-X.

Team, R.C., 2013. R: A Language and Environment for Statistical Computing. R Foundation for Statistical Computing, Vienna, Austria.

Thompson, K., Bakker, J.P., Bekker, R.M., 1997. The Soil Seed Banks of North West Europe: Methodology, Density and Longevity Vol. 1 Cambridge university press.

Thomsen, S.R., Berglund, S., Worlund, I., 1991. Assessing the validity of the logit method for ecological inference. Eur. J. Polit. Res. 19 (4), 441-477. https://doi.org/10.1111/ j.1475-6765.1991.tb01197.x.

Tison, J.-M., de Foucault, B., 2014. Flora gallica: flore de France. Biotope Mèze.

Vaquero, M., 2005. Soil physical properties and banana root growth. Presented at the Banana Root System: Towards a Better Understanding for Its Productive Management. Proceedings of an International Symposium Held in San José, Costa Rica on 3-5 November 2003, International Network for the Improvement of Banana and Plantain (INIBAP). pp. 125-131.

Venables, W., Ripley, B., 2002. Random and mixed effects. Modern Applied Statistics With S. Springer, pp. 271-300.

Von Der Lippe, M., Kowarik, I., 2007. Long-distance dispersal of plants by vehicles as a driver of plant invasions. Conserv. Biol. 21 (4), 986-996. https://doi.org/10.1111/j. 1523-1739.2007.00722.x.

Walter, H., 1971. Ecology of Tropical and Subtropical Vegetation. Oliver and Boyd, Edinburgh.

Westermann, J.R., von der Lippe, M., Kowarik, I., 2011. Seed traits, landscape and environmental parameters as predictors of species occurrence in fragmented urban railway habitats. Basic Appl. Ecol. 12 (1), 29-37. https://doi.org/10.1016/j.baae. 2010.11.006.

Whitford, V., Ennos, A.R., Handley, J.F., 2001. "City form and natural process"-indicators for the ecological performance of urban areas and their application to Merseyside, UK. Landsc. Urban Plan. 57 (2), 91-103. https://doi.org/10.1016/ S0169-2046(01)00192-X.

Wiens, J.A., Stenseth, N.C., Horne, B.V., Ims, R.A., 1993. Ecological mechanisms and landscape ecology. Oikos 66 (3), 369. https://doi.org/10.2307/3544931.

Williams, N.S.G., Hahs, A.K., Vesk, P.A., 2015. Urbanisation, plant traits and the composition of urban floras. Perspectives in Plant Ecology. Evol. Syst. 17 (1), 78-86. https://doi.org/10.1016/j.ppees.2014.10.002.

Willson, M.F., Traveset, A., 2000. The ecology of seed dispersal. Seeds: Ecol. Regener. Plant Commun. 2, 85-110.

Wittig, R., Becker, U., 2010. The spontaneous flora around street trees in cities-a striking example for the worldwide homogenization of the flora of urban habitats. Flora Morphol. Distrib. Funct. Ecol. Plants 205 (10), 704-709. https://doi.org/10.1016/j. flora.2009.09.001.

Wood, S.N., 2017. Generalized Additive Models: An Introduction with R. CRC press.

Zipperer, W.C., Wu, J., Pouyat, R.V., Pickett, S.T.A., 2000. The application of ecological principles to urban and urbanizing landscapes. Ecol. Appl. 10 (3), 685. https://doi. org/10.2307/2641038. http://www.tela-botanica.org. 